\title{
Kontynuacja i zmiany w polskim republikanizmie XVII i XVIII wieku
}

I. Tradycja republikańska I Rzeczypospolitej obejmuje dorobek bardzo wielu autorów, zarówno teoretyków, jak i publicystów, działających na przestrzeni trzech stuleci, poczynając od pierwszej połowy wieku XVI, kiedy to namysł polityczny formułowany był pod przemożnym wpływem humanizmu i renesansu. Celem tego artykułu jest próba dokonania podstawowych ustaleń dotyczących zmian, jakie zachodziły w polskim dyskursie republikańskim w XVII i XVIII wieku oraz kontynuacji, która ten dyskurs w dużej mierze charakteryzuje. Wychodząc od podstawowych założeń i osiągnięć szesnastowiecznej teorii republikańskiej, głównym przedmiotem analizy czynię najbardziej reprezentatywne ujęcia teoretyczne szlacheckiego dyskursu republikańskiego XVII wieku oraz nowe wątki, jakie wnoszą do tego dyskursu republikańscy reformatorzy w czasach Oświecenia. Będę dowodzić, że zmiany zachodzące $\mathrm{w}$ polskim republikanizmie miały inny charakter niż zmiany zachodzące $\mathrm{w}$ republikanizmie zachodnim, który stawał się coraz bardziej otwarty na wyzwania nowożytności (w szczególności w Anglii i w Ameryce), ulegając dalszej transformacji, co przejawiało się łączeniem tego, co zawarte w klasycznym wzorcu republiki z niektórymi ideami nowożytnymi, np. z ideą przyrodzonych uprawnień, konstytucjonalizmem, ochroną prywatnej własności i przedsiębiorczością. Polski republikanizm miał inne podłoże społeczne i był specyficzny w tym sensie, iż chciał za wszelką cenę trzymać się wzorca klasycznego, który jakoby miał być uosobiony w ustroju Rzeczypospolitej; miał więc charakter zachowawczy i do pewnego stopnia zamknięty na idee, które rozwijały się gdzie indziej (inaczej niż jeszcze w wieku XVI). Co więcej republikanizm szlachecki opierał się w większym stopniu na tradycji greckiej niż rzymskiej, która w XVII wieku popychała autorów angielskich w kierunku radykalnego przeciwstawienia republiki i monarchii. Zabrakło u nas tego fermentu intelektualnego, jaki niosła wojna domowa w Anglii i wyswobodze- 
nie się spod zwierzchnictwa Korony w koloniach amerykańskich. Dopiero wyraźne zagrożenie dla dalszego trwania Rzeczypospolitej w drugiej połowie XVIII wieku stało się przyczyną gwałtownego ożywienia dyskursu politycznego, którego rozkwit nastąpił podczas Sejmu Czteroletniego i debaty wokół Konstytucji 3 Maja. Schyłek wieku XVIII przynosi próby włączenia do dyskursu republikańskiego nowych idei, takich jak idea naturalnych uprawnień człowieka oraz wolności osobistej, nie zapoznając jednak całkowicie ustaleń wcześniejszych.

Do podjęcia tego tematu skłania co najmniej kilka powodów. Tradycja republikańska I Rzeczypospolitej wciąż jeszcze wymaga wielu badań, także o charakterze porównawczym. Terminem tym obejmuje się prawie trzy stulecia w dziejach Polski, konieczne jest więc uchwycenie dynamiki dyskursów politycznych zakorzenionych $\mathrm{w}$ dziedzictwie republikańskim, ale odpowiadających najczęściej na potrzeby praktyczne. Ponadto, szczegółowe ustalenia dotyczące polskiej teorii republikańskiej XVI wieku, jakie przedstawiłam w monografii Ład Rzeczypospolitej. Polska myśl polityczna XVI wieku a klasyczna tradycja republikańska ${ }^{1}$, skłaniają mnie do postawienia kolejnego pytania, które dotyczy wpływu tej teorii na późniejszy dyskurs republikański. Konieczne wydaje się badanie nie tylko stanowisk różnych autorów XVII i XVIII wieku kojarzonych z teorią republikańską, ale także kontynuacji i zmian, jakie zachodzą $\mathrm{w}$ namyśle republikańskim, odnoszącym się zawsze w mniejszym czy większym stopniu do konkretnego bytu politycznego, jakim była Rzeczpospolita Obojga Narodów. Artykuł ten jest jedynie przyczynkiem do takich badań i zawiera raczej postulaty badawcze oraz propozycję określonego kierunku badań niż ostateczne rozstrzygnięcia. Przyjętą przeze mnie cezurą czasową są czasy Sejmu Czteroletniego, nie analizuję jednak szczegółowo ani jego debat, ani polemiki wokół samej Konstytucji $3 \mathrm{Maja}^{2}$, w jakie zaangażowali się autorzy republikańscy.

Pierwsza teza, jaką chciałabym postawić, głosi, że o ile głównym problemem teorii republikańskiej XVI w. jest pytanie o istotę dobrze urządzonej Rzeczypospolitej, namysł dotyczący związku między prawem i sprawiedliwością a wolnością i cnotą, o tyle w wieku XVII, szczególnie w drugiej połowie, oraz w pierwszej połowie wieku XVIII wątkiem kluczowym szlacheckiego republikanizmu staje się zachowanie wolności, środki temu służące (liberum veto i wolna elekcja) i przeciwstawienie wolności absolutum dominium. W wieku

${ }^{1}$ D. Pietrzyk-Reeves, Lad rzeczypospolitej. Polska myśl polityczna XVI wieku a klasyczna tradycja republikańska, Kraków 2012.

${ }^{2} \mathrm{Na}$ ten temat zob. A. Grześkowiak-Krwawicz, O formę rządu czy o rzad dusz? Publicystyka polityczna Sejmu Czteroletniego, Warszawa 2000; R. Lis, Między Konstytucja 3 Maja a Targowica. Poglądy polskich republikantów w latach 1791-1793, „Czasopismo Prawno-Historyczne” 2012, t. LXIV, z. 2, s. 161-189 oraz R. Lis, Myśl reformatorska Sejmu Czteroletniego w świetle dylematów zachodniego republikanizmu XVIII wieku. Zarys problematyki, „Horyzonty Polityki” 2013, t. 4, nr 7, s. 15-45. 
XVI dominuje teoretyczny namysł nad normatywnymi podstawami ładu politycznego, którego wolność, zarówno wspólnoty politycznej, jak i obywatela, jest pochodną, nie może go bowiem wyprzedzać. Uznanie wolności jako kluczowej cechy ładu Rzeczypospolitej w wieku XVII każe czynić z tego pojęcia punkt wyjścia do rozważań o Rzeczypospolitej, prawie, sprawiedliwości czy cnocie. Dominują te stanowiska, które widząc w formie rządu Rzeczypospolitej gwarancję wolności, tę to formę każą za wszelką cenę utrzymać3 , podczas gdy w wieku XVI dominujący jest postulat naprawy Rzeczypospolitej. Zarazem jednak da się wskazać na pewien istotny aspekt namysłu republikańskiego, który w polskiej teorii politycznej jest obecny od wieku XVI po czasy Sejmu Czteroletniego i pozwala mówić także o wyraźnej kontynuacji. Jest to przekonanie, którego źródło znajdujemy już w antycznej tradycji republikańskiej, zarówno w teorii Arystotelesa, jak i Cycerona, że dobrze urządzony ład polityczny to res publica, wolna i praworządna wspólnota polityczna, w której suwerenem jest prawo oparte na sprawiedliwości i wyznaczające zarówno swobody, jak i obowiązki obywateli, których powinnością jest troska o Rzeczpospolitą, kierowanie się cnotą i unikanie zepsucia. Miała to być wspólnota samorządna oparta na ustroju mieszanym równoważącym trzy elementy: monarchiczny (król), arystokratyczny (Senat) i demokratyczny (Izba Poselska i sejmiki). W XVIII wieku pojawiają się jednak odstępstwa od koncepcji ustroju mieszanego z jednej strony, $\mathrm{z}$ drugiej zaś od koncepcji suwerenności prawa na rzecz suwerenności narodu szlacheckiego.

Druga teza tutaj stawiana, być może bardziej kontrowersyjna, zakłada, że trzeba oddzielić dwa poziomy dyskursu - publicystyczny, odnoszący się wybitnie do praktyki, i teoretyczny odnoszący się do filozoficznie uzasadnianych normatywnych podstaw ładu politycznego. To przeciwstawienie jest szczególnie istotne, gdy porównamy namysł republikański XVI i XVII w.; w wieku XVI ton nadaje dyskurs teoretyczny, w wieku XVII zaś dyskurs praktyczny. Republikanizm schyłku XVIII w. jest natomiast o tyle specyficzny, że przynosi rozkwit dyskursu teoretycznego powodowany celami wybitnie praktycznymi i pozostający pod wyraźnym wpływem nowożytnej, a nie antycznej myśli politycznej.

Z dzisiejszej perspektywy można oczywiście postawić tezę, że słabością republikanizmu XVII i XVIII wieku, nawet tego z drugiej połowy wieku XVIII, jest zbyt daleko idąca zachowawczość, zbyt mało krytycyzmu wobec rozwiązań instytucjonalnych Rzeczypospolitej, którym republikanizm ten dawał uzasadnienie teoretyczne, w porównaniu z teorią republikańską XVI w. wskazującą, że instytucje muszą odpowiadać normatywnym i moralnym pod-

${ }^{3}$ Łukasz Opaliński w Apoteozie polskiej wolności stwierdza: „Tę to mianowicie najdawniejszą formę rządu, zupełnie zgodną z naturą i rozumem, nadzwyczaj pożyteczną i korzystną, niegdyś przejęliśmy i stale aż dotąd zachowujemy". Tenże, Obrona Polski, przeł. K. Tyszkowski, Wrocław 1959, s. 198. 
stawom ładu, że o te podstawy trzeba zadbać, by Rzeczpospolita mogła być państwem wolnym i dobrze urządzonym. Tak naprawdę jednak przekonanie, że moralne podstawy ładu politycznego (cnota) mają znaczenie kluczowe dla jego trwania było obecne $\mathrm{w}$ dyskursie republikańskim od samego początku, nadając polskiemu republikanizmowi specyficznego charakteru, idącego w innym kierunku niż republikanizm zachodni przyjmujący za Wenecją tezę o konieczności „mechanizacji cnoty”, czyli wprowadzenia takich rozwiązań prawnych i instytucjonalnych, które chroniłyby ład polityczny przed zagrożeniami wynikającymi z niedostatku cnoty, ze słabości kondycji moralnej człowieka ${ }^{4}$. Przedstawiciele republikanizmu angielskiego i amerykańskiego postulowali zabezpieczenie ustroju mieszanego rozwiązaniami konstytucyjnymi i prawnymi, takimi jak podział władzy, odpowiedni system wyborczy i zasada reprezentacji, nie sposób bowiem polegać na cnocie obywateli i ich stałej trosce o dobro wspólne. Co więcej, w XVIII w. coraz częściej mówi się o republice kupców, pozostawiającej na uboczu wolność polityczną, czyli udział obywateli w stanowieniu prawa samorządnej republiki, a republikanizm zaczyna zbliżać się do liberalizmu. Przeobrażenia w polskim republikanizmie nie miały tak radykalnego charakteru, jak choćby w republikanizmie angielskim XVII w., w którym do głosu dochodzi stanowisko zdecydowanie antymonarchiczne $^{5}$, czy w nowym republikanizmie amerykańskich Ojców Założycieli w wieku XVIII, ujawniających wprawdzie nostalgię za ideałami klasycznej tradycji republikańskiej, ale postulujących zupełnie nowożytne rozwiązania $\mathrm{z}$ całkowitym odrzuceniem elementu monarchicznego $\mathrm{w}$ ustroju mieszanym i koncentracją na elementach instytucjonalnych ładu politycznego z podziałem władz i zasadą reprezentacji na czele ${ }^{6}$. Nowożytny republikanizm obejmować będzie projekty o tyle odmienne od tych, które wykształciła klasyczna tradycja republikańska, iż szukające podstaw ładu rzeczypospolitej nade wszystko $\mathrm{w}$ porządku instytucjonalnym, a nie moralnym, nie tyle $\mathrm{w}$ prawie opartym na wyższej sprawiedliwości, ile w podziale i równowadze władzy, nie tyle w cnocie każdego obywatela, ile w zabezpieczeniu przed dominacją, w osłabieniu skutków zepsucia, w zastąpieniu monarchicznej formy rządów niemonarchiczną republiką. W Polsce związek z klasyczną tradycją republikańską miał pozostać silny aż do drugiej połowy XVIII w.

${ }^{4}$ Zob. szerzej J.G.A. Pocock, The Machiavellian Moment: Florentine Political Thought and the Atlantic Republican Tradition, Princeton, Princeton University Press 1975; V. Conti, The Mechanisation of Virtue: Republican Rituals in Italian Political Thought in the Sixteenth and Seventeenth Centuries, [w:] Q. Skinner, M. van Gelderen, Republicanism: A Shared European Heritage, Cambridge 2002, t. 2, s. 75-80.

${ }_{5}$ Zob. M. Peltonen, Classical Humanism and Republicanism in English Political Thought 1570-1640, Cambridge-New York 1995.

${ }^{6}$ Zob. szerzej S. Filipowicz, Pochwała rozumu i cnoty. Republikańskie credo Ameryki, Kraków 1997. 
II. Tradycja republikańska I Rzeczypospolitej kształtowała się pod wpływem antycznych idei republikańskich, których początku szukać trzeba w filozofii Arystotelesa, w jego ustaleniach dotyczących istoty i celu wspólnoty politycznej oraz dobrego ładu politycznego. Znajdują one kontynuację i rozwinięcie w starożytnym Rzymie, szczególnie w refleksji Cycerona, Polibiusza i jego teorii ustroju mieszanego, Seneki, Liwiusza, Salustiusza ${ }^{7}$. Do tych właśnie autorów nawiązują wszyscy niemal polscy autorzy republikańscy XVI i XVII wieku. Najistotniejszym elementem teorii republikańskiej, znajdującym szerokie odzwierciedlenie w polskim dyskursie, jest przekonanie, że dobry ład polityczny (w węższym sensie dobry ustrój) nie sprowadza się do rozwiązań instytucjonalnych, do mechaniki ustrojowej, lecz znajduje wsparcie we właściwie ukształtowanym charakterze człowieka, czyli w cnocie. Taką konstatację znajdujemy i u Arystotelesa i u Cycerona dowodzących, że najistotniejszą podstawą rzeczypospolitej jest „ład normatywny”, czyli ustalenia dotyczące sprawiedliwości i prawa oraz wspierającej je i kształtowanej przez nie doskonałości etycznej obywateli (arete, virtus) ${ }^{8}$. Polska szesnastowieczna teoria republikańska, bliska „momentowi Arystotelesowskiemu”, wydaje się w tym zasadniczym punkcie różnić od republikanizmu zachodniego, zarówno szesnasto-, jak i siedemnastowiecznego, w którym zdaje się przeważać „moment rzymski” akcentujący ład instytucjonalny (wyartykułowany w XVI wieku przez Machiavellego w Rozważaniach nad pierwszym dziesięcioksięgiem historii Rzymu Liwiusza) znajdowany w tradycji antycznej przede wszystkim u Polibiusza i Tacyta, a w mniejszym stopniu u Cycerona. Utrwalone w tej tradycji pojęcie res publica odnosi się przede wszystkim do treści wspólnoty politycznej, a nie tylko do jej formy, do celu i sensu samorządnej wspólnoty obywatelskiej, którą Cyceron określa mianem rzeczy publicznej (res populi), a nie tylko do ustalenia, kto w tej wspólnocie sprawuje najwyższą władzę.

Powrót do antycznego namysłu politycznego przynosi okres renesansu, w pierwszej kolejności w miastach północnych Włoch, ale także w Niemczech, w Anglii i Szkocji, a nade wszystko w Rzeczypospolitej pozostającej w bliskich stosunkach kulturowych z Italią i innymi ośrodkami życia umysłowego w Europie. Zwrot republikański dokonał się w Polsce w XVI wieku zarówno pod wpływem promieniującego z Włoch humanizmu, jak i ewolucji ustrojowej i politycznej, prowadzącej do utrwalenia się ustroju mieszanego

7 Takiemu ujęciu, wskazującemu na grecko-rzymską syntezę idei republikańskich, na którą zwraca uwagę także Pocock (The Machiavellian Moment..., passim) sprzeciwił się np. Eric Nelson w książce The Greek Tradition in Republican Thought, Cambridge 2004, twierdząc, że nie ma czegoś takiego, jak „klasyczny republikanizm”, ponieważ rzymska filozofia polityczna nie wyrasta w oczywisty sposób z filozofii greckiej Platona i Arystotelesa (s. 4).

${ }^{8}$ M.T. Cicero, O państwie, [w:] tenże, O państwie; O prawach; O powinnościach; O cnotach, przeł. W. Kornatowski, Warszawa 1960, III.31, s. 141-142, III.23, s. 134. 
i zasady parlamentaryzmu, rządów prawa i wolności ${ }^{9}$. Szlachecki „naród polityczny" świadomy swoich praw i powinności zaczął tworzyć wspólnotę obywatelską, biorąc aktywny udział w stanowieniu prawa i utrwalaniu ładu civitas libera, którym był żywotnie zainteresowany. Dokonująca się wówczas recepcja wartości republikańskich służyła zrozumieniu i uzasadnieniu związanego z tym doświadczenia politycznego i wzorców, które miały nim kierować. Już wtedy, w drugiej połowie XVI wieku okazało się, że nie sposób mówić o jednym tylko dyskursie republikańskim w związku z ujawniającym się napięciem (którego świadomi byli zarówno stoicy, jak i epikurejczycy) między takimi kategoriami, jak jednostka i wspólnota, rozum i wola, suwerenność prawa i suwerenność państwa albo ludu. Okazuje się, że przedstawiciele polskiej teorii republikańskiej, przyjmujący kluczowe ustalenia Arystotelesa i Cycerona dotyczące właściwie urządzonego ładu rzeczypospolitej, zaczynają różnie określać punkt wyjścia tego ładu, podmiot, do którego się odnosi, szukając go bądź w organicznej całości, jaką jest wspólnota polityczna (jak choćby w projekcie Frycza Modrzewskiego, Przyłuskiego, Goślickiego), bądź w poszczególnych częściach ciała zbiorowego oraz w tworzących je jednostkach (jak w projekcie Orzechowskiego i szlacheckich publicystów) $)^{10}$. Zwolennicy pierwszego ujęcia byli zwykle niechętni wzmacnianiu czynnika demokratycznego w ustroju mieszanym, widząc źródło stabilności i prawowitości tego ustroju w czynniku arystokratycznym (Goślicki, a w Wenecji Contarini), lub monarchicznym (Frycz Modrzewski, Warszewicki) ${ }^{11}$. Zwolennicy ujęcia drugiego obawiali się ograniczenia głosu obywateli, postulując raczej przewagę czynnika demokratycznego, obejmującego w kontekście polskim wyłącznie przedstawicieli szlachty. Nie dostrzegali oni, iż może się okazać, że nie sposób uzgodnić interesu konkretnej grupy z dobrem całości, że już w tym wyodrębnieniu pewnej grupy jednostek i utożsamieniu z nią całej rzeczypospolitej kryje się niebezpieczeństwo odchodzenia od teleologicznego ujęcia ładu i jasno zakreślonego celu, jakiemu miał służyć, a którym było dobro całej wspólnoty politycznej. Zastanawiając się nad tym, kto najlepiej mógłby się o ten cel troszczyć, autorzy republikańscy proponowali co najmniej dwa rozstrzygnięcia. Pierwsze

9 Szerzej na ten temat zob. A. Wyczański, Polska w Europie XVI stulecia, Poznań 1999, s. 102-106, 147; W. Uruszczak, Sejm walny w epoce złotego wieku (1493-1569), [w:] Społeczeństwo obywatelskie i jego reprezentacja (1493-1993), red. J. Bardach, Warszawa 1995, s. 52; H. Olszewski, Sejm w dawnej Rzeczypospolitej. Ustrój i idee, t. 2: Studia i rozprawy, Poznań 2002, s. 69 i n.; D. Pietrzyk-Reeves, Ład rzeczypospolitej, s. 180-190. Por. K. Koehler, Wstęp, [w:] Stanisława Orzechowskiego i Augustyna Rotundusa debata o Rzeczypospolitej, red. Krzysztof Koehler, Kraków 2009, s. 12.

${ }^{10}$ Można zaryzykować tezę, że projekty republikańskie formułowane w I Rzeczypospolitej, od wieku XVI po wiek XVIII, nie przyniosły ostatecznego rozstrzygnięcia tej kwestii.

${ }^{11}$ Chcę tu podkreślić, że pewnym nieporozumieniem jest (w odniesieniu do tych koncepcji, które są zakorzenione w klasycznej tradycji republikańskiej) nieuznawanie za republikańskie ujęć autorów opowiadających się za wzmocnieniem monarchii w ustroju mieszanym, a zarazem uznających wszystkie zasadnicze ideały klasycznej tradycji republikańskiej. 
głosiło, że cel ten należy powierzyć obywatelom wyróżniającym się mądrością i cnotą, tym, którzy zasłużyli na szlachectwo swoim postępowaniem i zasługami dla wspólnoty politycznej, bo potrafią chętnie i odpowiedzialnie wypełniać obowiązki służby publicznej i są niepodatni na zepsucie, kierując się zawsze troską o dobro całości, a nie względem na interes własny. Drugie rozstrzygnięcie koncentruje się bardziej na wolności i prawach jednostek-obywateli, które ład Rzeczypospolitej ma umożliwiać i zabezpieczać, dostrzegając w ustroju mieszanym, którego czynnik monarchiczny - król - miał być wybierany przez wszystkich obywateli na zasadzie wolnej elekcji, ostoję wolności i równości oraz gwarancję praw obywateli. Cnota i troska o dobro wspólne są tu pożądane, lecz nie przesądzają o kwalifikacji obywatelskiej. Spór ten będzie istotny także w dwóch kolejnych stuleciach.

Można, w moim przekonaniu, wskazać na trzy zasadnicze tezy dyskursu republikańskiego Rzeczypospolitej, które pozwalają mówić o jego kontynuacji, poczynając od wieku XVI, kiedy formułowane są po raz pierwszy, po drugą połowę wieku XVIII, czyli czasy Oświecenia, tezy znajdujące swoje źródło w antycznej tradycji republikańskiej. Pierwsza teza głosi, że państwo to rzeczpospolita, wolna wspólnota polityczna. Druga teza dodaje, że wolność tej wspólnoty politycznej i jej członków-obywateli wynika z ładu normatywnego, tj. z oparcia jej na sprawiedliwości i prawie oraz obwarowania cnotą i dobrymi obyczajami, a w większym jeszcze stopniu z praw politycznych, z samostanowienia obywateli uczestniczących czynnie w stanowieniu prawa, któremu podlegają. Wreszcie teza trzecia głosi, że wolny i praworządny ład gwarantuje ustrój mieszany złożony z trzech elementów: monarchicznego, arystokratycznego i demokratycznego. Nacisk w tym dyskursie położony jest zasadniczo na to, co spaja, na wspólnotę polityczną i jej etos, przy dostrzeżeniu zagrożeń płynących z przewagi tego, co partykularne. Natomiast stosunek do konkretnych rozwiązań ustrojowych, tj. stosunek do liberum veto, zasady elekcji króla i roli monarchy w ustroju mieszanym, czy ustawiczności sejmu różnicują stanowiska republikańskie zarówno w XVII, jak i w szczególności w wieku XVIII.

III. Nowy rys teorii republikańskiej w porównaniu z ustaleniami szesnastowiecznymi zapowiadają już u początku XVII wieku pisma z czasów rokoszu Zebrzydowskiego, szczególnie te, które koncentrują się na pojęciu libera respublica przeciwstawianego absolutum dominium. Ten ostatni termin wywoływał w XVII w. najgorsze skojarzenia, nie dostrzegano różnicy między monarchią absolutną a tyranią czy despotią, przypisując władzy absolutnej atrybuty utożsamiane z niewolą. Anonimowy autor z czasów rokoszu Zebrzydowskiego określał absolutum dominium jako ,foeda servitus",12, ,przykrą,

12 Libera respublica - absolutum dominium - rokosz, [w:] Pisma polityczne z czasów rokoszu Zebrzydowskiego, 1606-1608, wyd. J. Czubek, Kraków 1918, t. 2, s. 410. 
smrodliwą niewolę", podkreślając, że kto w takim państwie żyje, jest faktycznie niewolnikiem, bo okazywać musi władcy absolutny posłuch. „Pod takowym prawem nullum dogma, żadna ustawa, żadne prawo powagi nie ma", sam bowiem władca stanowi prawo w myśl zasady sic volo, sic iubeo, quod libet licet ${ }^{13}$. W publicystyce terminem absolutum dominium zaczęto się posługiwać jako straszakiem dla utrącenia prób reform zmierzających do wzmocnienia władzy centralnej czy nawet usprawnienia obrad sejmu. W literaturze rokoszowej zaczyna się utrwalać przekonanie, że suwerenność, czyli summa potestas regni, przypada nie trzem stanom sejmującym bądź królowi, lecz stanowi szlacheckiemu, który część uprawnień dobrowolnie przekazuje wybranemu przez siebie władcy. Na zasadę tę poniekąd wskazywał już diariusz sejmu z 1592 roku głoszący: „Każdy z nas jest dziedzicem tego królestwa, na które króla obieramy, i to tak, aby nam rozkazował wedle prawa" ${ }^{14}$. Inaczej niż na zachodzie termin „lud" używany był przez polskich publicystów na określenie szlachty, nie obejmując ani mieszczaństwa, ani tym bardziej chłopów. Rzeczpospolita, jak przekonywał Andrzej Maksymilian Fredro, miała być „rzecząpospolitą ludowo-monarchiczną”, czyli taką, w której szlachta-lud ma władzę zwierzchnią, choć na czele tego państwa stoi król ${ }^{15}$. Państwu „monarchicznemu” przeciwstawił on szczęśliwe państwo republikańskie, gdzie władza zwierzchnia podporządkowana prawu uchwalonemu przez obywateli zabezpiecza ich przed kaprysami losu, tj. kaprysami absolutnego władcy. Jednym ze środków zabezpieczających przed ograniczeniem wolności i absolutum dominium stało się z czasem stosowanie liberum veto, jakie Fredro uznał za wspólny mianownik, dzięki któremu demokracja i monarchia mogły współistnieć w postaci republikańskiej ${ }^{16}$. Zwolennicy zniesienia liberum veto mieli, w jego przekonaniu, zmierzać do pozbawienia obywateli wolności. Temu samemu celowi, czyli zabezpieczeniu wolności służyć miała wolna elekcja i niezgoda na zasadę dziedziczenia tronu, zaś jej praktycznym przejawem było uczestnictwo szlachcica-obywatela w życiu publicznym traktowane jako szkoła obywatelskich cnót. Jak pisał anonimowy szlachcic: „wielkie utrapienie Rzpltej naszej dzieje się dla nieporządku i niedbalstwa nas samych i z inszych wielu miar, że my nie oddawamy tego, cośmy po-

13 Tamże.

14 Diariusz sejmowy z 1592 r., [w:] Diariusze $i$ akta sejmowe r. 1591-1592, wyd. E. Barwiński, Kraków 1911, s. 208, Scriptores Rerum Polonicarum, t. 21.

15 Od takiego ujęcia odszedł zdecydowanie Aleksander Olizarowski podnoszący, że chłopi bezprawnie uczynieni zostali w Polsce ludźmi niewolnymi, podważając tezę, jakoby ustrój nasz był prawdziwie mieszany, skoro nie ma w nim elementu demokratycznego, czyli udziału we władzy ludu, czyli plebejuszy. Zob. tenże, De politica hominum societate, Gdańsk 1651, s. 152-198 .

16 A.M. Fredro, „W obronie liberum veto”, fragm. Responsum in gratami cujusdam sermonis privati, bonone fiat Reipublicae Polonae... (1660), przeł. F. Wujtewicz, [w:] Filozofia i myśl spoteczna XVII wieku, s. 305. 
winni, ojczyźnie swojej”'17. Wskazywał dalej i na konieczność obrony ojczyzny, uznawanej za obowiązek obywatelski, oraz przestrzegania zasad sprawiedliwości, oddawania każdemu tego, co mu się należy, i na praworządność. Był to ten kluczowy moment historyczny, kiedy starły się różne wyobrażenia ładu Rzeczypospolitej i zasadnicze stało się pytanie, czy przeważą te o charakterze substancjalnym, czy też te o charakterze instrumentalnym. Fredro jest też przedstawicielem tych autorów siedemnastowiecznych, którzy opowiadali się przeciwko ustanowieniu stałego sejmu, utożsamiając taki zabieg $\mathrm{z}$,wprowadzeniem do Rzeczypospolitej, pod złudnym pozorem i niepostrzeżenie, zupełnej tyranii"'18. Inaczej do tej kwestii podszedł współczesny Fredry Łukasz Opaliński, opowiadający się za reformą sejmową i atakujący liberum veto (powstrzymując się jednak przed głoszeniem zasady większości) ${ }^{19}$. W innym zupełnie kierunku będą iść autorzy republikańscy czasów saskich, w szczególności Stanisław Karwicki, a w drugiej połowie XVIII w. Szymon Konarski, dostrzegający coraz wyraźniej problematyczność rozwiązań instytucjonalnych Rzeczypospolitej.

Republikanizm wieku XVII staje się republikanizmem szlacheckim, jest to doktryna jednej warstwy i z perspektywy tej jednej warstwy jest traktowana i uzasadniana, czego nie da się w sposób tak oczywisty powiedzieć o wieku poprzednim. Wyraża się to już w przywoływanej wyżej literaturze rokoszowej z lat 1606-1608, która suwerenność, czyli władzę najwyższą w państwie wolnym, jakim miała być Rzeczpospolita, przypisuje już tylko stanowi szlacheckiemu, który dobrowolnie przekazuje część swoich uprawnień wybranemu przez siebie królowi. „Stan rycerski jest fundamentem istius Reipub.”, jak głosił Zamoyski, twierdząc, że sejmy są po to, by jego członkowie si quid nocivum esset in Repub. id communi auxillio et consilio avertatur ${ }^{20}$.

W XVI w. dominowało pojmowanie wolności w związku z cnotą oraz prawem, jest ona pochodną praworządnego ładu politycznego Rzeczypospolitej, jest możliwa dzięki prawu, którego źródłem jest wola tych, którzy mu podlegają, oraz dzięki współuczestniczeniu w stanowieniu praw i decydowaniu o sprawach państwa. Wolność w Rzeczypospolitej miała być wolnością pod prawem, ale prawem stanowionym przez wolnych obywateli; stanowienie prawa, któremu się podlega, było głównym znamieniem tej koncepcji wolności, którą odnajdujemy w tradycji republikańskiej. Aspekt ten został szczególnie

17 Votum szlachcica polskiego, [w:] Pisma polityczne z czasów rokoszu Zebrzydowskiego, s. 62 .

18 A.M Fredro, Cautio Reipublicae, seu durationis omen, w: Scriptorum seu togae et belli notationum fragmenta, Gdańsk 1660, cyt. za: Filozofia i myśl spoleczna XVII wieku, w thumaczeniu F. Wujtewicza, s. 312.

19 Por. Z. Ogonowski, Filozofia polityczna w Polsce XVII wieku i tradycje demokracji europejskiej, Warszawa 1999, s. 27-41.

${ }^{20}$ Mowa Zamoyskiego na Sejm 1605 r., [w:] Pisma polityczne z czasów rokoszu Zebrzydowskiego, t. 3, s. 479. 
wyostrzony w retoryce szlacheckiej od XVI w. poczynając, Dwie zasadnicze cechy filozofii politycznej i publicystyki politycznej XVII wieku to wspomniana nienawiść do absolutyzmu (z którym jednak nikt nie podjął rzeczowej teoretycznej polemiki, ponieważ nie było takiej praktycznej potrzeby) oraz uznanie wolności za wartość naczelną w życiu społeczno-politycznym ${ }^{21}$. Wolność miała wyróżniać Rzeczpospolitą Obojga Narodów spośród wszystkich ówczesnych państw. Była to z jednej strony wolność od ingerencji władzy, obejmująca zarówno nietykalność osobistą, prawo własności, jak i wolność polityczną do współudziału w życiu publicznym i decydowaniu o wszystkich sprawach lokalnych, do współkształtowania wraz z innymi obywatelami losów narodu i państwa. Akcentowano również, że wolność to życie w państwie prawa, idąc za republikańskimi autorami XVI w., takimi jak Frycz Modrzewski czy Wolan, inspirowanymi pismami Arystotelesa i Cycerona. Pod koniec XVII w. Stanisław Lubomirski istotę polskiej wolności upatrywał w tym, że faktycznym władcą w Rzeczypospolitej jest prawo, że wszystkie stany, król, senatorowie i stan rycerski, są podporządkowane temu samemu prawu ${ }^{22}$. Przekonanie, że wolność to przede wszystkim samostanowienie obywateli, przetrwało do końca I Rzeczypospolitej, choć pod koniec XVIII w. uzupełniono je o bliskie teorii zachodniej rozróżnienie dwóch poziomów wolności, o czym jeszcze będzie mowa. W r. 1775 Michał Wielhorski pisał: „wolność Polaka na tym zawisła, aby temu tylko prawu był posłusznym, które on albo sam przez siebie, albo przez wybrane do prawodawstwa osoby ustanowił"23. Tak rozumiana wolność nie mogła być realizowana w państwie opartym na silnej władzy, jak to, które postulował Hobbes, a jedynie w republice, czyli w wolnej rzeczypospolitej opartej na ustroju mieszanym. Ta koncepcja nie uległa właściwie zmianie do XVIII w., jej wyrazem było jawne negowanie wszelkich rozwiązań instytucjonalnych, które mogłyby prowadzić do absolutum dominium, czyli np. jakiegokolwiek wzmocnienia władzy królewskiej, choć za takim wzmocnieniem opowiadali się wyraźnie niektórzy, przywoływani wcześniej autorzy XVI w.

${ }^{21}$ Uczestnicy dyskusji politycznych, a szerzej ogół szlachty, stali się współuczestnikiem i współposiadaczem wolności, czyniąc tę kategorię paradygmatem teorii politycznej. Spowodowało to swoistą jałowość dyskursu teoretycznego, bowiem, jak zauważyła Anna Grześkowiak-Krawicz, od końca XVI w. po lata 80. wieku XVIII nikt nie analizował wolności jako takiej, nie traktowano jej jako abstrakcyjnej kwestii filozoficznej czy zagadnienia z zakresu teorii państwa, jak czyniło to wielu pisarzy na zachodzie Europy. Polscy autorzy problem ten rozpatrywali zawsze w odniesieniu do rzeczywistości polskiej, w jakimś sensie do siebie samych jako przedstawicieli stanu szlacheckiego. A. Grześkowiak-Krwawicz, Regina libertas. Wolność w polskiej myśli politycznej XVIII wie$k u$, Gdańsk 2006, s. $46-47$ i passim.

${ }^{22}$ S.H. Lubomirski, De vanitate cansiliorum liber unus, in quo vanitas et veritas rerum humonarum politicis et moralibus rationibus clare demonstratur et dialogice exhibiteur, 1699. Polskie wydanie: O znikomości rad, Warszawa 1916, s. 37.

${ }_{23}$ M. Wielhorski, O przywróceniu dawnego rzadu wedlug pierwiastkowych Rzeczypospolitej ustaw, b.m., 1775, s. 111. 
Z drugiej strony była to wolność wynikająca z niezależności wspólnoty politycznej jaką była Rzeczpospolita od czynników zewnętrznych, umożliwiająca wolność pierwszą, o którą jednak, co paradoksalne, z czasem dbano mniej niż o wolność samostanowienia i niezależność osobistą, wymagała ona bowiem ponoszenia ciężarów na cele obronne i stałej gotowości do tego, by owej niezależności bronić. Zapominano jednak, że bez civitas libera nie będzie wolnych obywateli. Wątek ten, w tym postulat powołania stałej armii, będzie najmocniej reprezentowany dopiero w drugiej połowie XVIII w. kiedy po pierwszym rozbiorze zdano sobie sprawę, że wolność civitas libera chwieje się w swoich podstawach i wymaga radykalnych środków naprawczych. Jedną z najbardziej charakterystycznych cech pism politycznych XVII w., nieobecną jeszcze w takim natężeniu w dyskursie republikańskim XVI w., było uznanie za niebezpieczne zalecanie takiego programu reform, który by ograniczał zasięg swobód obywatelskich albo opatrywał je dodatkowymi wymaganiami i zmierzał do wzmocnienia władzy centralnej czy choćby usprawnienia całej machiny państwowej, np. obrad sejmu (co w XVI w. postulowało wielu czołowych autorów republikańskich). To uznanie wolności, a nie np. sprawiedliwości, czego domagał się jeszcze Frycz Modrzewski, za naczelną cechę ustroju przekładało się na pojęcie wolnego państwa i przekonanie, że Polacy w innym niż wolne państwie żyć nie potrafią, że to wyróżnia ich niejako spośród innych narodów.

W myśli politycznej XVI w., która szczególnie mocno czerpała z antycznej tradycji republikańskiej, obfitując w wybitne traktaty polityczne o sporym zacięciu teoretycznym, dominował wątek naprawy Rzeczypospolitej (co widać nawet w tytułach dzieł, O poprawie Rzeczypospolitej A. Frycza Modrzewskiego czy anonimowej Naprawie Rzeczypospolitej). Pisarze polityczni odwoływali się do republikańskich ideałów dobrze urządzonego praworządnego ładu politycznego, zakorzenionego w wyższych normach prawa oraz obywatelskich cnót i powinności, aby ukazać wady dostrzegane w polskim ustroju politycznym i systemie prawnym. Pojawiły się wówczas również konkretne projekty reform, jak choćby w pismach Frycza i Łukasza Górnickiego. Ów wątek naprawy schodzi na dalszy plan, jeśli nie znika zupełnie, w drugiej połowie wieku XVII. Nawet kontynuatorzy namysłu republikańskiego obawiali się jakichkolwiek reform i zmian w ładzie instytucjonalno-prawnym, postulując utrzymanie istniejącego status quo (w XVI w. takie podejście można było znaleźć właściwie jedynie w pismach St. Orzechowskiego). Było to zgodne z poglądami dominującymi wśród szlachty, która po konstytucji Nihil novi uznała zasady ustroju politycznego za ustalone i wymagające bardzo niewielu korekt i uzupełnień, domagając się za to stale egzekucji istniejących praw. Poza tym wojny, w jakie uwikłana była Rzeczpospolita w XVII wieku sprawiły, że szukano oparcia w utrwalonych w świadomości zasadach republikańskiego ładu jako jedynej trwałej ostoi politycznej, nie był to sprzyjający 
okres na jakąkolwiek zasadniczą korektę, nawet w duchu republikańskim, dominujących idei i zasad, w tym wolnej elekcji i liberum veto.

Jak wspomniałam na początku, już w XVI w. zarysował się spór o to, kto ma mieć przewagę w ustroju mieszanym Rzeczypospolitej, poczynając od stanowisk Warszewickiego i Skargi, domagających się wzmocnienia władzy królewskiej, po Sebastiana Petrycego z Pilzna, który w osłabieniu monarchii widział niechybne zagrożenie trwałości ładu politycznego ${ }^{24}$. Apogeum tego sporu przypada na początek wieku XVII i ujawnia się w pismach z czasów rokoszu sandomierskiego, którego źródłem był opór wobec prób wzmocnienia pozycji ustrojowej króla przez Zygmunta III Wazę, posądzonego o chęć ustanowienia w Polsce absolutum dominium na wzór monarchii zachodnich. W pochodzącej z pierwszej połowy XVII w. Rozmowie plebana z ziemianinem o teraźniejszym stanie Rzeczypospolitej Łukasza Opalińskiego przedstawiona została dyskusja między zwolennikiem wzmocnienia władzy króla i odejścia od ludowej form rządu a orędownikiem utrzymania dawnej wolności i swobód głoszącego: „Ale my, cośmy to jarzma i jugów ciężkiego panowania nieświadomi, cośmy skosztowali jako jest miła i słodka wolność, nie chcemy mieć pana inakszego, tylko który by sedem principis occupet, ne sit domino locus" 25 . W rozmowie tej pojawia się typowy dla polskiego dyskursu republikańskiego topos, znajdowany już u Cycerona i cytowanego przez Opalińskiego Salustiusza, głoszący, że przyczyną kryzysu ładu politycznego Rzeczypospolitej jest odejście od cnót i zwyczajów przodków i zapoznanie najważniejszego obowiązku obywatelskiego, jakim jest troska o dobro i całość Rzeczypospolitej. Rozmówcy zgadzają się też z tezą Machiavellego wyrażoną w Rozważaniach, iż tak jak obyczaje, by mogły nieodmiennie trwać, potrzebują dobrego prawa, tak i prawo, aby było zachowane, potrzebuje dobrych obyczajów ${ }^{26}$. Opaliński przywołuje także dzieło Gaspara Contariniego o Rzeczypospolitej Weneckiej omawiającego urzędy weneckie, w tym ten,

${ }^{24}$ Sebastian Petrycy był przeciwnikiem wolnej elekcji, dowodząc, że rozsądek wskazuje, iż lepiej jest dla Rzeczypospolitej, jeżeli posiada dziedzicznego króla niż elekta, elekcja bowiem, zwłaszcza taka, która wymaga zgody wszystkich stanów, prowadzi do podziałów i ,rozerwania między elektorami”, dlatego też „elekcja, która by od wszystkich stanów zgodna miała być, nie może być lepsza niż dziedzictwo” (S. Petrycy z Pilzna, Przydatki do „Polityki” Arystotelesowej, [w:] tenże, Przydatki do „Ekonomiki” i „Polityki” Arystotelesowej, oprac. W. Wąsik, Warszawa 1956, s. 226, Pisma wybrane, t. 2, s. 249-250). Uwagi te sprawiły, że niektórzy badacze zaliczyli Sebastiana Petrycego do monarchistów, a nie republikanów wbrew jego całościowej wizji Rzeczypospolitej.

${ }^{25}$ Ł. Opaliński, Rozmowa plebana z ziemianinem o teraźniejszym stanie Rzeczypospolitej, [w:] tenże, Wybór pism, Warszawa 1959, s. 41-42. Jest to traktat napisany w duchu najlepszej tradycji republikańskiej, pełen odniesień do autorów starożytnych oraz współczesnych szesnastowiecznych włoskich republikanów Machiavellego i Contariniego.

${ }^{26}$ N. Machiavelli, Rozważania o dziesięcioksięgu historii Rzymu Liwiusza, przeł. K. Żaboklicki, Warszawa 2009. W Polsce w taki sam sposób wypowiadał się Łukasz Górnicki w: Droga do zupetnej wolności, [w:] tenże, Pisma, t. 2, oprac. R. Pollak, Warszawa 1961, s. 484. 
który bezstronnie karze naruszających publiczne prawa, konkludując, że bojaźń oskarżenia i karania zatrzymuje w powinności tych, których „sumienie i cnota zatrzymać nie może"27. Ustami Plebana wyrażona jest tutaj krytyka liberum veto i wymóg zgody wszystkich, które mając być osłoną wolności, wolność tę znoszą ${ }^{28}$. W innym dziele, Obrona Polski, przedstawia Opaliński apoteozę polskiej wolności (szlacheckiej) nawiązującą w swojej wymowie do Stanisława Orzechowskiego i pism z czasów rokoszu Zebrzydowskiego, uznającą niewolę za najgorszą klęskę życia doczesnego: „nienawidzimy jej gorzej niż żmii [...] kochamy zaś wolność $\mathrm{i}$, co jest z tym jednoznaczne, cenimy ową wolność, nie powiem: złotą, lecz bezcenną, która jest szczególnym darem ducha [...] błogosławiona nasza ojczyzna z powodu tego daru Boga"29. Autor dodaje, niejako ustami szlachty: „Zajmujemy się Rzecząpospolitą, gdy nam się tak podoba. Nie zmuszani, bierzemy na się obowiązki, nie składamy ich bez przyczyny, choćby na rozkaz. Bezpiecznie możemy pędzić życie prywatne, sprawowanie urzędów nie naraża na żadną obawę [...] Tak szczęśliwy pędzimy żywot, któremu niczego dodać nie można [...]"30. Jest to możliwe w ustroju mieszanym, w którym król nie jest panem stojącym nad prawami, lecz prawom podlega, nie stoi ponad obywatelami, lecz obywatelom jest dany ${ }^{31}$. Podobnie jak w wieku XVI, ustrój mieszany uznawany był przez siedemnastowiecznych publicystów republikańskich za formę ustrojową najpożyteczniejszą i najkorzystniejszą, gwarantującą najdłuższe trwanie państwa i największą pomyślność obywateli, w którym prawa stają się strażnikiem władzy.

Zbigniew Ogonowski skonstatował słusznie, że „filozofia polityczna w Polsce XVII w. jest konserwatywna, zapatrzona w przeszłość, nie zdradza zainteresowania nowymi prądami ideowymi, ani takich nie proponuje i jest nastawiona na obronę status quo. Broni ona jednak idei i wartości, które w tradycji demokracji europejskiej są dziś wysoko cenione, a które wówczas były rzadko obecne, poza Anglią" ${ }^{32}$. Do idei tych autor zaliczył ideę suwerenności ludu rozumianego jednak tylko jako jedna warstwa, czyli szlachta, ideę państwa prawa, wykorzystywaną jednak, jak dodaje, na użytek szlachty, ,ułomną ideę reprezentacji”, którą psuje zasada liberum veto, nie pozwalając na wypracowanie nowoczesnej teorii reprezentacji, jaką wykształcił republikanizm angielski, a następnie amerykański, ideę wolności jednostki i wolnego państwa,

${ }^{27}$ Machiavelli, Rozważania, s. 52.

${ }^{28}$ W tym miejscu Opaliński przywołuje Piliniusza głoszącego, że „w publicznych naradach nic nie jest tak niesprawiedliwe, jak sama równość, albowiem uprawnienie wszystkich jest jednakowe, chociaż roztropność wszystkich jest różna”. Opaliński, Rozmowa plebana z ziemianinem, s. 59.

${ }^{29}$ Ł. Opaliński, Obrona Polski, przeł. K. Tyszkowski, [w:], tenże, Wybór pism, s. 196.

30 Tamże, s. 197.

31 Tamże, s. 198.

32 Z. Ogonowski, Filozofia polityczna XVII wieku, s. 103. 
czyli civitas libera, którego istnienie tę wolność gwarantuje, ideę równości obywateli oraz ideę tolerancji religijnej ${ }^{33}$. Dowodem kontynuacji namysłu republikańskiego oprócz utrwalenia tych idei przez pisarzy i publicystów politycznych są rozliczne siedemnastowieczne pisma i traktaty polityczne. Reformacyja obyczajów polskich Szymona Starowolskiego, wydana w 1650 r., wpisuje się w typowy dla polskiego dyskursu republikańskiego topos, rozważany najpełniej na płaszczyźnie teoretycznej, dotyczący związku wolności z prawem i cnotą, nieutożsamiający wolności z przywilejami i wolnościami szlachty, lecz szukający istoty „prawdziwej wolności”. W tym celu autor odwołuje się zarówno do autorytetów starożytnych, Cycerona i Seneki, jak i do Andrzeja Frycza Modrzewskiego głoszącego, że prawdziwa wolność nie polega na swobodzie postępowania zgodnie z własną wolą, lecz na poskramianiu złych skłonności i wad ${ }^{34}$. Powtórzone tu zostało słynne twierdzenie Cycerona, wielokrotnie przywoływane przez autorów republikańskich XVI wieku, które Starowolski sformułował następująco: „posłuszeństwo prawu nie czyni nas niewolnikami, ale prawdziwie wolnymi, prawdziwie szczęśliwymi" ${ }^{35}$. Co więcej, Starowolski nawiązał do tych autorów starożytnych, np. Sallustiusza, którzy uważali, że istnieje ścisły związek pomiędzy moralnością obywateli (cnotą) a stanem rzeczypospolitej.

$\mathrm{W}$ porównaniu $\mathrm{z}$ republikanizmem siedemnastowiecznym, w okresie Oświecenia na plan dalszy odchodzi przekonanie, iż kluczową podstawą ładu republikańskiego jest cnota, co widać szczególnie w pismach Stanisława Konarskiego porzucającego ten typowy dla polskiego dyskursu republikańskiego wątek, na czoło zaś wysuwa się dyskusja dotycząca niektórych zasad ustrojowych, w tym przede wszystkim wolnej elekcji i liberum veto. Rozważenie, czy zasada liberum veto zgodna jest z ideałami teorii republikańskiej, przekracza zakres tego artykułu. Niemniej sprawa jest poważna, zważywszy na to, że wielu spośród pisarzy politycznych i publicystów XVII w. popierało, a nawet broniło tej zasady jako gwarancji wolności kojarzonej z samostanowieniem, czyli podleganiem tylko takim prawom, na które wyraża się zgodę. Zasada jednomyślności, przeciwstawiana zasadzie większości, miała chronić z jednej strony przed „fakcyjnością”, jak to określał A.M. Fredro ${ }^{36}$, z drugiej strony przed wzrostem potęgi majestatu królewskiego, który tę większość mógłby na swoją korzyść urabiać37. „Wolne nie pozwalam” miało gwarantować, iż ci, którzy się kierują prawdziwą cnotą i troską o dobro publiczne, mogą

33 Tamże, s. 104.

34 Sz. Starowolski, Reformacya obyczajów polskich wszystkim stanom ojczyzny naszej..., Varsaviae 1692, s. 28.

35 Tamże, s. 141.

36 A.M. Fredro, Responsum in gratim cujusdam sermonis private, bonone fiat Reipublicae Polonae..., przeł. F. Wujtewicz (fragm.) w: Filozofia i myśl spoleczna XVII wieku, s. 302.

37 Tamże, s. 305. 
w każdej chwili tak pokierować obradami sejmu, że nie dopuszczą niczego, co miałoby przynieść szkodę Rzeczypospolitej. Brak tej zasady sprawiałby, że ,wszystko, co dla dobra publicznego będą chcieli uczynić nieliczni, zostałoby udaremnione, a wszystko, cokolwiek dla zaspokojenia swoich ambicji chciałaby uzyskać większość (a mógłbym powiedzieć: fakcyjność), zostałoby urzeczywistnione" ${ }^{38}$. W wywodzie tym Fredro przyjmuje założenie, że już starożytni stosowali zasadę weta, dopuszczając wybitne autorytety do tego, by w sprawach państwa wyrażali ostateczny, decydujący głos. A przecież zasada ta sama w sobie nie gwarantuje, że weto wobec uchwalanych ustaw będą wyrażać tylko najcnotliwsi, tylko ci, którzy zawsze nad własne stawiają dobro Rzeczypospolitej.

W XVI w. publicyści republikańscy mówili raczej o zgodzie niż o jednomyślności, podkreślając, że jest to „mur bezpieczny [...] do zachowania w całości Ojczyzny" ${ }^{\prime 3}$. Polityka oparta na zgodzie nie wymagała jednomyślności, lecz umiejętności porozumienia i osiągania kompromisu, tego, na co zwracał uwagę Machiavelli w odniesieniu do republiki rzymskiej i ujawniających się w niej konfliktów, czyli zasady wypracowywanego w ogniu debat na forum parlamentu kompromisu ujawniającego różnice stanowisk i ścieranie się opinii, których końcowy rezultat, jak wymagała teoria republikańska, miał przychylać się do tego, co najkorzystniejsze dla wspólnoty politycznej, co ma charakter ponadpartykularny. Idąc tym tokiem myślenia, należałoby podkreślić, że dyskusja i dialog miały nadawać sejmowym przetargom formę racjonalną, deliberatywną, zapewniać przewagę argumentów nad emocjami ${ }^{40}$ oraz przyczyniać się do utrzymania równowagi w ustroju mieszanym. Co ciekawe, argumentacja Fredry, poprzestająca raczej na retoryce, niż opierająca się na rzetelnej argumentacji, pomija już te wątki, które były kluczowe dla autorów XVI w. sceptycznie odnoszących się do zasady powszechnej zgody lub jednomyślności, wyrażanych czy to przez Warszewickiego, czy Sebastiana Petrycego z Pilzna. Ten ostatni opowiadał się za rozwiązaniem najbardziej w jego mniemaniu zgodnym z rozsądkiem, bo skoro nie sposób oczekiwać, by każda decyzja była podejmowana za zezwoleniem wszystkich, rozwiązaniem najwłaściwszym jest przyjąć to, co większa część uradzi, „to ma być miasto wszystkich" 41 .

Pod koniec XVII w. liberum veto uznawane było za źrenicę wolności, a jego obrona została zaliczona do największych cnót obywatela. Słabość Rzeczypospolitej dostrzegano nie w porządku instytucjonalno-prawnym, lecz

38 Tamże, s. 302.

39 Philopolites to jest Miłośnik Ojczyzny, albo o powinności dobrego Obywatela, Ojczyźnie dobrze chcącego i onę mitującego, Kraków 1588, k. 6B-7A.

40 Zob. szerzej J. Ekes, Trójpodziat władzy i zgoda wszystkich. Naczelne zasady „, ustroju mieszanego" w staropolskiej refleksji politycznej, Siedlce 2001, s. 114 i n.

41 S. Petrycy z Pilzna, Przydatki do Polityki..., s. 392. 
w ułomności, niecnotliwości każdego obywatela, twierdzono „prawa mamy dobre, tylko sami jesteśmy źli, nic do nich przydać nie możemy" 42 . Wiąże się to $\mathrm{z}$ wielkim przywiązaniem do starych form ustrojowych, do prerogatyw szlacheckich i wolności. Zabrakło w polskim republikanizmie tego, co najpierw dostrzeżono w Wenecji, czyli „mechanizacji cnoty”, co ujawnia się w pismach XVII-wiecznych republikanów angielskich z Jamesem Harringtonem na czele, czyli obwarowania ładu Rzeczypospolitej raczej rozwiązaniami instytucjonalnymi, formalnymi, aniżeli cnotą obywateli. Zabrakło też namysłu, tak jeszcze dojrzałego w wieku XVI, nad istotą ustroju mieszanego, nad tym, jaki rodzaj równowagi i umiarkowania jest konieczny dla jego pomyślnego trwania, a przede wszystkim dla pomyślności państwa, które się na nim opiera. Wypada jednak zauważyć, że była to w dużej mierze kontynuacja namysłu politycznego wcześniejszego, szesnastowiecznego, szukającego podstaw ładu Rzeczypospolitej w prawie i cnocie, ale też stale postulującego „,naprawę" tego ładu, sprostanie wymogów cnoty publicznej i sprawiedliwości, bez których wolność przekształca się w swawolę, a zepsucie (korupcja) zagraża dobru publicznemu, co z czasem mogło przekuć się w konkretny program naprawy instytucji. Na to jednak trzeba było poczekać aż do drugiej połowy XVIII w. „Wiek srebrny”, jak go określają niektórzy badacze, nie przyniósł traktatów politycznych, które by temu wyzwaniu sprostały i które zbliżyłyby się do tego kierunku rozwoju, jakim poszedł republikanizm zachodni, osobliwie angielski i amerykański.

Dopiero najwybitniejsi osiemnastowieczni autorzy republikańscy opowiedzieli się przeciwko liberum veto, poczynając od Karwickiego po Kołłątaja. Uznali oni, że zasada ta podważa instytucje wolnego państwa oraz uderza w same podstawy wolności republikańskiej, której istotą była możliwość samostanowienia, stając się jej przeszkodą ${ }^{43}$. Liberum veto $\mathrm{W}$ przekonaniu Stanisława Leszczyńskiego zagrażało samej Rzeczypospolitej pozbawiając ją najwyższej władzy, czyli władzy prawodawczej, a w zamian dając władzę despotyczną ,partykularnemu obywatelowi”44. Bardzo wyraźnie w tej kwestii wypowiedział się jeden z najbardziej wpływowych republikanów XVIII w., ks. Stanisław Konarski sprzeciwiający się zasadzie jednomyślności i postulujący zasadę większości, bez której niemożliwe miało być utrzymanie wolności politycznej, którą liberum veto czyniło pozorną. Zasada ta była nie do pogodzenia ze sprawnym sejmowaniem i instytucją przedstawicielstwa, co Konarski dostrzegał jeszcze wyraźniej niż Karwicki i Leszczyński, głosząc, że bez sejmów, czyli podstawowej instytucji wolnego państwa, zginie sama

42 Cyt. za H. Olszewski, Doktryny prawno-ustrojowe czasów saskich, s. 19.

43 A. Grześkowiak-Krwawicz, Veto - wolność - władza w polskiej myśl politycznej wieku XVIII, „Kwartalnik Historyczny” 2004, R. 111, nr 3, s. 155.

${ }^{44}$ S. Leszczyński, Głos wolny wolność ubezpieczający, wyd. J. Turowski, Kraków 1858, s. 77 . 
Rzeczpospolita ${ }^{45}$. Podkreślał on, że nie widzi w całym Volumen Legum żadnego prawa, które usprawiedliwiałoby stosowanie liberum veto ${ }^{46}$. Wolny głos nie był dla niego równoznaczny z 'wolnym nie pozwalam', jak powszechnie uznawała szlachta, odnosił się przecież do swobody opinii i wypowiedzi, która jednak nie mogła w żaden logiczny sposób przekładać się na podważanie decyzji większości, jeżeli ta $\mathrm{z}$ taką opinią nie byłaby zgodna. Konarski więc, „ostatecznie, w sposób spójny, logiczny i konsekwentny rozdzielił, a właściwie przeciwstawił liberum veto - rozumiane jako nieograniczona władza jednostki - wolności tak całej społeczności, jak pojedynczego obywatela"47. Późniejsze głosy w tej kwestii wypowiadane w czasach stanisławowskich były zgodne z ustaleniami Konarskiego, zresztą nie tylko w kwestii veta ${ }^{48}$, ale także w kwestii zasady większości jako będącej dużo praktyczniejszym rozwiązaniem niż zasada jednomyślności. Nawet jednak wówczas uznawano, że istnieją pewne fundamentalne prawa Rzeczypospolitej, różnie zresztą pojmowane, dla zmiany których konieczna jest zgoda wszystkich.

IV. W pierwszej połowie XVIII w., w czasach saskich dominuje przywiązanie szlachty do dawnych form ustrojowych, czego dowodem jest „wielka ilość pism, broszur z tego właśnie okresu, zajmujących się tylko wykładem prerogatyw szlacheckich, przypominaniem i wyliczaniem wszystkich wolności" ${ }^{49}$. Nie w naprawie instytucji i praw, lecz w niedostatku cnót obywatelskich upatrywana jest słabość państwa, skoro jak twierdzi publicysta „Polska nasza przypatrzywszy się monarchiom, to jest absolutus Imperii, arystokracjom, to jest panowaniu wielu rządców, demokracjom, to jest rządom pospólstwa, co najwyborniejsze wybrała sobie prawa i zwyczaje"50. Myśl polityczna tego okresu była całkowicie zamknięta na inspiracje zewnętrzne, co poniekąd wynikało z uznania, że wolność polska przewyższa wszystkie ustroje europejskie, jak głosił Władysław Łubieński w $1740 \mathrm{r}^{51}$, zapoznając niejako wszystkie te rozstrzygnięcia teorii republikańskiej wieku XVI i XVII, które osadzały wolność w szerszym ładzie normatywnym, czyniąc ją pochodną tego ładu, wiążąc wolność z wymogami sprawiedliwości, prawa i cnoty. „Wolność miała już nie tyle gwarantować wszystkie inne dobra, ile w jakimś sensie je zastę-

45 S. Konarski, O skutecznym rad sposobie albo o utrzymywanie ordynaryjnych seymów, Warszawa 1923, cz. III, s. 33-37, 279-281.

46 Tamże, s. 37.

${ }^{47}$ A. Grześkowiak-Krwawicz, Veto - wolność - władza..., s. 156.

48 Przekonanie w tej kwestii zmienił nawet wcześniejszy zwolennik tej zasady Michał Wielhorski, zgadzając się teraz, że liberum veto jest szkodliwe dla wolności.

${ }^{49}$ H. Olszewski, Doktryny prawno-ustrojowe czasów saskich, s. 19.

${ }^{50}$ Polityk to jest statysta polski senatowi, poselskiej izbie i rycerskim kołom na sejmowe i sejmikowe rady i mowy..., Bibl. Jag., rkps. 3545, k. 5.

${ }^{51}$ Zob. W.A. Łubieński, Świat we wszystkich swoich częściach większych i mniejszych to jest: w Europie, Azyi, Afryce y w Ameryce..., Wrocław 1740, s. 362 i n. 
pować" 52 , który to pogląd niewiele już miał wspólnego z klasyczną tradycją republikańską. Pierwsza połowa XVIII w. to także okres dominacji liberum veto, zarówno w praktyce, jak i w publicystyce i ujęciach teoretycznych, prowadzący do utożsamiania tej zasady z wolnością, z wolnościowym prawem każdej jednostki, które to rozumienie widać nawet w pismach Karwickiego ${ }^{53}$. Mimo palącej potrzeby wobec powszechnego upadku moralnego i gospodarczego autorzy republikańscy nie potrafili konieczności reform, zniesienia liberum veto, reformy sejmu czy reform skarbowo-wojskowych, przekuć na skuteczne postulaty praktyczne. Nie znalazły zrozumienia traktaty Karwickiego (Exorbitancye we wszystkich trzech stanach Rzeczypospolitej i poszerzona wersja tego De ordinanda Reipublicae) i Stanisława Szczuki (żądanie odebrania magnatom królewszczyzn i przeznaczenia na dochód Rzeczypospolitej), ani Głos wolny Leszczyńskiego. Zdaniem tego ostatniego autora tragedia Rzeczypospolitej tkwiła w konflikcie między majestatem a wolnością, w próbie łączenia monarchii i demokracji; szlachta krępuje króla, król chce się z tych więzów wyzwolić i żaden z tych stanów nie wypełnia dobrze swoich powinności ${ }^{54}$. Słuszne było, zdaniem Leszczyńskiego, przywiązanie do wolności danej Polakom od Boga, trzeba jednak uważać, by nie szafować nią pochopnie. Nie jest przejawem wolności, kiedy protestujący poseł narzuca swą wolę ogółowi, kiedy wola jednostki może być równoznaczna z niewolą wielu. Nie tak mieli rozumieć wolność dawni Polacy. Prawdziwa wolność miała polegać na podporządkowaniu woli jednostek Rzeczypospolitej, która jako całość miała najwyższy autorytet, była panią swych praw. Sięgał więc Leszczyński do ustaleń dawniejszej teorii republikańskiej, budując koncepcję Rzeczypospolitej jako całości stojącej wyżej niż monarcha, senat i szlachta, dostrzegając, że prawdziwa wolność musi wynikać nie z wywyższenia jednostki, lecz z podporządkowania jej dobru państwa. Szedł za tym postulat stworzenia nowoczesnego parlamentaryzmu poprzez ograniczenie stosowania liberum veto i wprowadzenie sejmu gotowego oraz zreformowania (ale nie zniesienia) wolnej elekcji. Nie chodziło tu o zmianę fundamentów ładu Rzeczypospolitej, lecz o nadanie im właściwej formy ${ }^{55}$. Podobnie jak Goślicki w XVI w., autor Głosu wolnego uznał wyjątkową rolę senatu w ustroju mieszanym, głosząc, że „nic bardziej nie charakteryzuje statum liberum w kró-

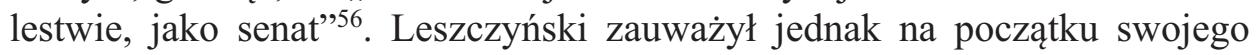
traktatu, że kwestia naprawy Rzeczypospolitej jest najmniej pożądana wśród

52 A. Grześkowiak-Krwawicz, Regina libertas ..., s. 299.

53 S. Dunin Karwicki, O potrzebie urzadzenia rzeczypospolitej (De ordinanda Republica), [w:] tenże, Dzieła polityczne z początku XVIII wieku, przeł. i oprac. A. Przyboś, K. Przyboś, Kraków 1992, s. 105.

${ }^{54}$ St. Leszczyński, Głos wolny ..., s. 8 i n.

55 Tamże, s. 6.

56 Tamże, s. 49. 
szlachty, a każdy głos, który by się do niej odnosił, jest zbywany milczeniem i ignorowany: „materya reformacyi, choć najlepszej, stanu rzpltej naszej, jest u nas jak księga zakazana"57. Przypomnijmy, że to właśnie kwestia naprawy dominowała $\mathrm{w}$ dyskursie republikańskim XVI wieku i jeszcze pierwszej połowy wieku XVII, a więc wtedy, gdy byt Rzeczypospolitej w żaden sposób nie był jeszcze zagrożony i wynikała z zapatrzenia we wzorzec ładu politycznego, jakiego istotę oddawała sama nazwa „,rzeczpospolita”.

Za najbardziej dojrzałą koncepcję republikańską z tego okresu uważana jest przez badaczy koncepcja Karwickiego, który główne zło i zagrożenie, wbrew tradycji republikańskiej, widział w samym ustroju mieszanym, wyżej stawiając ustroje czyste i postulując albo wzmocnienie władzy króla, albo dalsze jej umniejszenie ${ }^{58}$. Należy on do tych autorów republikańskich, którzy dostrzegli konieczność nie tyle naprawy obyczajów, ile ładu instytucjonalnego, proponując cały program reformy parlamentarnej obejmujący wprowadzenie ustawicznych obrad sejmu i zlikwidowanie prawa weta oraz rezygnacji z tradycyjnej formy wolnej elekcji - elekcji viritim ${ }^{59}$.

W wieku XVIII najistotniejsze zmiany, jak również i osiągnięcia w myśleniu politycznym, w tym w dyskursie republikańskim, pojawiają się w drugiej połowie tego stulecia i są zdecydowaną odpowiedzią na zagrożenie dalszego trwania bytu Rzeczypospolitej. Coraz wyraźniejszy staje się także dialog, nieobecny w pierwszej połowie tego stulecia, z zachodnią filozofią polityczną. Niektórzy badacze mówią w odniesieniu do pisarstwa Hugona Kołłątaja, Stanisława Staszica, a także Józefa Pawlikowskiego i Franciszka Salezego Jezierskiego o nowym republikanizmie przygotowującym doktrynalnie uzasadnienie dzieła naprawy Rzeczypospolitej podjętego na Sejmie Czteroletnim. W drugiej połowie XVIII w., kiedy następuje ogromny rozkwit polskiej myśli politycznej, powraca niejako ten styl myślenia i pisania, jaki znamy i z przełomu wieków XVI/XVII i pierwszej połowy wieku XVII. Dominują rozważania poświęcone naprawie Rzeczypospolitej odnoszące się wybitnie do kontekstu polskiego. Ich autorzy znają i przywołują dzieła zachodnich filozofów politycznych (w szczególności Rousseau, Monteskiusza, Locke'a i Mably’ego), niemniej jednak wykorzystują je dla własnych celów, czyli dla tworzenia teorii politycznej silnie związanej z rzeczywistością polską i z aktualnymi problemami politycznymi, nie podejmując szerszych roz-

57 Tamże, s. 5

58 S. Dunin Karwicki, Egzorbitancyje we wszystkich trzech stanach rzeczypospolitej krótko zebrane..., [w:] tenże, Dzieła polityczne z początku XVIII wieku. ,Z tego widzimy, że u nas w Polszcze jest i królestwo, i rzeczpospolita, więc że są insze reguły władzy królewskiego panowania, insze rzeczypospolitej rządów, gdzie wolność o konserwacyją swoją stara się, a te tamtym w głowę przeciwne są maksymy dlategoż, że każda z tych do interesu swego naciąga rzeczy, stąd ustawiczna mieszanina być musi" (s. 27).

59 S. Dunin Karwicki, De ordinanda Reipublicae seu de corrigenda defectibus in statu Reipublicae Poloniae, wyd. S. Krzyżanowski, Kraków 1871. 
ważań o charakterze czysto normatywnym, abstrakcyjnym, jakie obecne były w namyśle republikańskim XVI wieku, i nie konstruując wizji idealnego ładu politycznego jako takiego. Co więcej, w rozważaniach tych na pierwszy plan wysuwa się odwołanie do własnej tradycji ustrojowej i ideowej, w szczególności republikańskiej, której recepcja dokonuje się jednak przez pryzmat ówczesnych ustaleń teorii politycznej, w tym w szczególności proponowanych przez Rousseau i Monteskiusza.

Jednak jeszcze na przełomie lat sześćdziesiątych i siedemdziesiątych XVIII w. dominują wątki tradycyjne, kwitnie republikantyzm, którego to terminu używa się w odniesieniu do stanowisk formułowanych w Polsce w latach 1767-75 dla wyodrębnienia polskiego republikanizmu na tle zachodniego. W Polsce bowiem był to republikanizm szlachecki, który różnił się od ogólnoeuropejskiej wersji demokratycznej obejmującej całe społeczeństwo, a nie dotyczącej tylko jednego stanu i antyfeudalnej. Poza tym polski republikantyzm, inaczej niż republikanizm zachodni, bardzo rzadko miał charakter antymonarchiczny, bardzo rzadko postulował całkowitą likwidację instytucji króla i zastąpienie go ciałem kolegialnym ${ }^{60}$. Republikanci jednak postrzegali monarchę jako tylko reprezentanta władzy, ograniczonego w swoich prerogatywach, wybieralnego i odpowiedzialnego przed przedstawicielstwem narodu. Republikantyzm odnosi się więc ,do tej wersji republikanizmu odwołującego się do utopii przeszłościowej i wpisanego w feudalną strukturę (pojęcie wolności i równości egzystuje tylko w granicach jednego stanu)" "61. To w okresie konfederacji barskiej dawne wyobrażenia o Polsce i świecie, które utrwaliły się w XVII w., święcić miały swój ostatni triumf. Z tego okresu pochodzi jednak dość niejednoznaczne dzieło Michała Wielhorskiego, o przywróceniu „pierwiastkowych Rzeczypospolitej ustaw”, w którym przyznawał, że „pospólstwo" jest częścią narodu, która powinna otrzymać prawa polityczne, bowiem, jak twierdził, ,wyłączenie pospólstwa od uczestnictwa Rządu jest oczywistym wolności uwłóczeniem"62. Postulat ten miał jednak znaczenie raczej retoryczne niż praktyczne. Jak dawni republikanie, Wielhorski, który miał zainspirować Rousseau do napisania Uwag nad Rzadem Polski, wskazał na zepsucie obyczajów, które ,upadla umysły obywatelskie”, nawiązując bez wątpienia do szesnastowiecznego przekonania, które znajdujemy np. u Frycza Modrzewskiego, iż dobre obyczaje, podobnie jak dobre prawa, są podporą ładu rzeczypospolitej. Ubolewając nad zaprzepaszczeniem troski o dobro publiczne, które miało być jedną z podwalin rzeczypospolitej, nawiązał do znanego republikańskiego toposu zepsucia cnót, obyczajów i praw sformułowanego po raz pierwszy przez Cycerona: „Lecz dziś wszystko inną wzięło

60 J. Maciejewski, Geneza i charakter ideologii republikanów 1767-1775, „Archiwum Historii Filozofii i Myśli Społecznej” 1971, t. 17, s. 40.

${ }^{61}$ Tamże, s. 48.

${ }^{62}$ M. Wielhorski, O przywróceniu dawnego rządu ..., s. 305. 
postać. Nie masz obyczajów, nie masz staropolskiej prostoty, mało zostało w nas gorliwości; smutna odmiana, która będąc źródłem nieszczęść naszych, ukazuje nam nieodbitą potrzebę przywrócenia Rzeczypospolitej do pierwiastkowego jej rządu i do postanowienia praw takich, które by wszystkie bezprawia zatarły i wykorzeniły" ${ }^{63}$. Zarazem jednak Wielhorski, „spadkobierca Leszczyńskiego i Konarskiego”, sformułować miał „ostatecznie nowy nurt naszego myślenia polityczno-historycznego - oświecony republikantyzm, który stał się najpoważniejszą kontrpropozycją oświeconego monarchizmu, który sformułowany został w kręgu królewskim"64.

$\mathrm{O}$ ile więc z pewnymi wyjątkami republikantyzm tego okresu uznalibyśmy za kontynuację typowego szlacheckiego republikanizmu, o tyle debaty lat osiemdziesiątych otwierają na oścież drzwi powiewowi nowego myślenia, które wnosi dość istotną rewizję do dyskursu republikańskiego, kierując go na zupełnie inne tory. Debaty te zaowocowały nowymi ujęciami teoretycznymi inspirowanymi ówczesną sytuacją historyczną Rzeczypospolitej, ale też osiągnięciami zachodniej filozofii politycznej odnoszonymi wybitnie do kontekstu polskiego. W tym nowym dyskursie starły się dawne i nowe wyobrażenia republikańskie, które przeanalizuję tutaj pokrótce w oparciu o pisma przeciwników i zwolenników sukcesji tronu, poświęcając szczególną uwagę dwóm autorom, którzy wnieśli największy wkład do ówczesnej debaty politycznej, czyli Hugonowi Kołłątajowi i Stanisławowi Staszicowi.

Spór zasadniczy, jaki kształtuje się w debacie politycznej z okresu Sejmu Wielkiego to spór o sukcesję tronu ujawniający się $\mathrm{w}$ debacie i polemice między zwolennikami i przeciwnikami dziedzictwa tronu w samym obozie republikańskim, prowadząc do swoistej polaryzacji stanowisk, jaka uwidacznia się w poświęconym tej kwestii piśmie Seweryna Rzewuskiego z 1789 r. pt. O sukcesyi tronu w Polszcze rzecz krótka. Broniąc staroszlacheckiego republikanizmu przywiązanego do traktowania wolnej elekcji jako źrenicy wolności, „twierdzy Rzeczypospolitej”, Rzewuski formułował kluczowy w tej debacie argument antymonarchiczny, iż zasada dziedzictwa tronu jest niezgodna $\mathrm{z}$ wolnością, podważa prawa kardynalne i jest nowością, którą tylko nieostrożni, nieznający tradycji politycznej proponować mogą. Ustanowienie w Polsce tronu dziedzicznego było zdaniem hetmana jednoznaczne $\mathrm{z}$ ustanowieniem niewoli ${ }^{65}$. Właściwszym rozwiązaniem miała być reforma zasady elekcji, która pozwoliłaby uniknąć zamieszania spowodowanego elekcją viritim. Wady, jakie wiązano z wolną elekcją, Rzewuski przypisał nadmiernemu przywiązaniu szlachty do zbytku i zaniedbywaniu obowiązków obywatelskich z jednej strony, z drugiej zaś słabości, w szczególności militarnej, samej Rze-

\footnotetext{
63 Tamże, s. xi.

64 Maciejewski, Geneza i charakter ideologii..., s. 80.

65 S. Rzewuski, O sukcesyi tronu w Polszcze rzecz krótka, Warszawa 1789, s. 4.
} 
czypospolitej ${ }^{66}$, kończył zaś konstatacją, iż jeśli skuteczna poprawa zasady wolnej elekcji nie jest możliwa lub jest „niemiła”, „Rząd na potym, bez Króla ustanowić”, dzięki czemu ,ustanie wzajemna walka wolności z Tronem”67, o której wcześniej pisał Karwicki. Co charakterystyczne, Rzewuski powołał się w tym miejscu na Benjamina Franklina i George'a Washingtona, uznając ich wybór instytucjonalny, czyli republikę bez króla, za właściwszy niż zasadę sukcesji tronu, bo służący wolności ${ }^{68}$. Znajdujemy w tej wypowiedzi nowy i radykalny wątek w dyskursie republikańskim, czyli uznanie, iż w Polsce jest do pomyślenia odejście od dotychczasowego modelu ustroju mieszanego, odejście od monarchia mixta i ustanowienie niemonarchicznej republiki, „wiecznego bezkrólewia”. Był to jednak z pewnością raczej zabieg retoryczny niż faktyczny postulat Rzewuskiego ${ }^{69}$. W swojej rozprawce Rzewuski staną także w obronie liberum veto, twierdząc: „Nie masz lepszego w świecie stróża Praw Kardynalnych i formy rządu, jak jest Prawo Liberii veto"70, dodając jednak, że nie musi się ono rozciągać na wszystkie prawa, lecz na te, które są fundamentem Rzeczypospolitej i utrzymują jej ustrój w niezmienionym stanie. Tutaj właśnie ujawnia się po raz kolejny najbardziej problematyczny wątek w tradycji republikańskiej, mianowicie stosunek do zasad ustrojowych, do instytucji i typowe dla wielu polskich republikanów przekonanie, iż jakiekolwiek zmiany w porządku instytucjonalnym Rzeczypospolitej, jaki się utrwalił w wieku XVI, powodują zagrożenie wolności. Przeciwko takiemu podejściu wystąpią autorzy polemizujący z Rzewuskim i jego krytyką sukcesji tronu z Hugonem Kołłątajem na czele, głoszącym, iż zasada dziedziczenia tronu w dalszym ciągu czyni króla „wykonawcą Praw Narodowych”, „pierwszym w Narodzie Urzędnikiem" "71 wiązanym prawem, który nie tylko wolności, osobliwie wolności cywilnej, nie zagraża, lecz zapewnia jej lepszą gwarancję, dając zaporę przemocy ze strony możnych i chroniąc przed zakusami sąsiednich tronów.

Argumentację Rzewuskiego przeciw sukcesji tronu rozwinął i rozszerzył Wojciech Turski w dwóch pismach z 1790 r.: Myśli o królach, o suk-

\footnotetext{
66 Tamże, s. 11-13.

67 Tamże, s. 45.
}

68 „A Franklin i Waszyngton, owe dusze cnolitwe, dusze wielkie, którym Ameryka wolność swoją, świat cały cześć i zadziwienie, a Polacy przykład są winni, pokazali światu, że w Rzeczachpospolitych Naród wolny, złej lub dobrej swej doli sam będąc twórcą nie koniecznie potrzebuje Królów, aby był szczęśliwy” (tamże). Wypowiedź tę Kołłątaj komentował następująco: „W tym przeto miejscu okazał dopiero Autor (S. Rzewuski), co zamyślał. Nie idzie mu o wieczne Prawo obierania Królów, lecz o wieczne Bezkrólewie, czyli, co na jedno wychodzi, o ułożenie Rzplitej bez Króla" (H. Kołłątaj, Uwagi nad Pismem, które wyszło pod tytułem: Seweryna Rzewuskiego [...] o Sukcessyi tronu w Polszcze rzecz krótka, Warszawa 1790, s. 65).

69 Por. E. Rostworowski, Korespondencja Szczęsnego Potockiego z Sewerynem Rzewuskim z lat 1788-1796, „Przegląd Historyczny” 1954, t. 45, s. 724-732.

70 Tamże, s. 19.

${ }^{71}$ H. Kołłątaj, Uwagi nad Pismem ..., s. 56. 
cesji, o przeszłym i przyszłym rządzie oraz Odpowiedź na dzieło ks. Hugona Kollątaja, prezentując zdecydowane postulaty na rzecz tezy o niemożliwości pogodzenia wolności z tronem oraz uznając zasadę dziedziczności tronu za równoznaczną z przekształceniem obywateli w poddanych. Postulat ograniczenia władzy króla dziedzicznego prawem przekonywał Turskiego do uznania, iż będzie to zaledwie „,ień króla”, „król ograniczony, znając władzę innych królów i swoją niemoc, tym więcej uciemiężać pragnie i starać się, że mu jest to prawem zakazano"72. Monarchia dziedziczna wcześniej czy później prowadzi więc do tyranii, czego przykładem miała być także Anglia, stawiana za wzór przez zwolenników sukcesji, w której naród nie jest „ludem prawdziwie wolnym" ${ }^{\text {"73 }}$. Argumentacji krytycznej i polemicznej w pismach Turskiego towarzyszyły także postulaty pozytywne utrzymane w duchu dawnej retoryki republikańskiej dotyczące zarówno rozumienia wolności, jak i rządności i naprawy Rzeczypospolitej, szczególnie tam, gdzie postulował: „nie badajmy dziś na próżno, czymeśmy byli, ale myślmy o tym, czym być powinniśmy. Myślmy od dawnego rządu oddalić wady, przydać doskonalsze poprawy: dawne wskrzesić dobre zwyczaje, nowe wprowadzić porządki, jak to już po części stało się dziełem naszym"74. Nowatorstwo to miało jednak mieć ściśle określone granice, wynikać raczej z rozpoznania nowego ducha czasów, niż z przyjęcia wzorów obcych, na co zwracał uwagę inny przedstawiciel republikantów tego okresu reprezentujący formację antysukcesyjną Adam Wawrzyniec Rzewuski, który głosił: „Przestańmy być Anglikami, zacznijmy być Polakami; błędy przodków naszych poprawmy, ale nie twórzmy konstytucji rządowej, całkiem nowej i nieznanej, do której umysł Polaka z trudnością mógłby przywyknąć. Wreszcie, jeżeli mam być niewolnikiem, jeżeli rząd jedynowładny postanowić chcecie, Polacy, spór tylko zachodzi o słowa, rzecz już jest zrobiona"75. Nie podejmując się szerszej interpretacji pism tych trzech autorów, zauważmy, że obok przywiązania do tzw. staroszlacheckiego republikanizmu, prezentują oni także nowe wątki, czyli np. krytykę klasycznego ustroju mieszanego (co znamy już z pism Karwickiego), czy postulat zwierzchności całej szlachty skupiającej w swoich rękach władzę prawodawczą, osłabiający dawniejszą zasadę suwerenności prawa, przy jednoczesnym uznaniu kluczowej roli obyczajów i cnoty.

Dużo bardziej istotne z punktu widzenia przedmiotu naszej analizy, czyli ewolucji polskiego republikanizmu, wydają się propozycje autorów republi-

${ }^{72}$ W. Turski, Myśli o królach, o sukcesji, o przeszłym i przyszłym rządzie, Warszawa 1790, s. 13.

73 W. Turski, Odpowiedź na dzieło ks. Hugona Kottątaja, Warszawa 1790, s. 68.

74 Tamże, s. 21-22. Zob. szerzej niedawną interpretację obydwu pism Turskiego R. Lis, Wojciech Turski przeciw sukcesji tronu. Próba ponownego odczytania myśli republikańskiej z okresu Sejmu Czteroletniego, „Politeja” 2011, nr 1(15), s. 415-450.

75 A.W. Rzewuski, O formie rządu republikańskiego, Kraków 2008, s. 158. 
kańskich zaliczanych do obozu reformatorskiego, twórców Konstytucji 3 Maja i zwolenników sukcesji tronu, wykraczających jednak znacznie w swoich rozważaniach poza polemikę dotyczącą tej ostatniej kwestii. Jak wspomniałam wyżej, polscy autorzy w okresie Oświecenia znali i wykorzystywali najnowsze teorie zachodnie (czego nie czynili w wieku poprzednim), nie podważając podstawowego założenia republikańskiego, że wolność może się realizować tylko w państwie wolnym. Dzięki wpływowi zachodnich teorii dokonano u nas rozróżnienia dwóch poziomów wolności: wolności cywilnej i wolności politycznej. Ta druga odnosiła się do samostanowienia, udziału we władzy. Ta pierwsza miała pozwalać obywatelowi czynić to wszystko, czego nie zabraniają prawa, w tym korzystać ze swojej własności. Panował powszechnie pogląd, obcy liberałom, że tylko wolność polityczna gwarantuje wolność cywilną. Nowością było idące za doktryną liberalną uznanie wolności cywilnej za naturalne prawo każdego człowieka, co pozwoliło włączyć sprawę chłopów do rozważań politycznych. Czołowi reformatorzy polscy, Kołłątaj i Staszic, dzięki tym zmianom w myśleniu stworzyli nowoczesną wizję zależnego od własnej woli narodu, mającego prawa cywilne (nieograniczane już tylko do szlachty), ale także wpływ na rządy państwem. W dyskursie tym wraca program naprawy Rzeczypospolitej, która staje się największą potrzebą chwili, o wiele bardziej palącą niż w XVI w. gdy już nie chodzi o to, czy państwo będzie oparte na właściwych podstawach etyczno-prawnych, lecz o to, czy przetrwa jako civitas libera.

Uwagi nad życiem Jana Zamoyskiego opublikowane przez Staszica w 1785 r. i biorące za wzór wybitnego przywódcę politycznego dawnej Rzeczypospolitej, podobnie jak Listy Anonima Kołłątaja wydane w latach 1788-1790, otwierały kluczowy dla ówczesnego namysłu republikańskiego wątek naprawy Rzeczypospolitej, korzystając i z dorobku największych autorów polskich, i z tego, jaki wypracowała ówczesna myśl zachodnia, przynosząc, jak wspomniałam, istotną rewizję dawnego, staroszlacheckiego republikanizmu. Staszic podważył przekonanie szlachty, że Polska jest prawdziwą rzecząpospolitą, w której realizowana jest wolność republikańska, skoro wolność ta tak naprawdę ograniczona jest tylko do jednego stanu i już dawno przekształciła się w swawolę. Aby stworzyć prawdziwą rzeczpospolitą należało włączyć w zakres jej praw i obowiązków wszystkie stany, tak by pojęcie dobra wspólnego nie odnosiło się tylko do jednego uprzywilejowanego stanu szlacheckiego, lecz obejmowało całe społeczeństwo. W tym celu należało też wzmocnić państwo i przywrócić właściwy związek między wolnością a obowiązkami obywatelskimi, w tym przede wszystkim obowiązek ponoszenia ciężarów - podatków - na cele obronne pozwalających na utrzymanie stałej armii i obronę ojczyzny. Były to wszystko cele pragmatyczne, choć wsparte wysublimowaną niekiedy argumentacją teoretyczną. Dzięki Staszicowi wytworzyć się mogła nowoczesna opinia publiczna pozbawiona tonu moraliza- 
torskiego i dawnej bezkrytycznej apologetyki, rozumiejąca i nowego ducha czasów, i sytuację Rzeczypospolitej ${ }^{76}$, umiejąca wykorzystać niektóre przynajmniej elementy ówczesnych teorii społecznych, w szczególności Condillaca, Rousseau i fizjokratów francuskich, których postulaty prawno-naturalne stawały się przydatnymi argumentami w formułowaniu wizji reform społeczno-politycznych ${ }^{77}$. Wpływ na refleksję polityczną wywarła także Konstytucja Stanów Zjednoczonych oraz francuska Deklaracja Praw Człowieka i Obywatela.

Co istotne i nowe dla późnego republikanizmu polskiego, obydwaj reformatorzy odeszli od dawnej zasady równości jedynie w obrębie stanu szlacheckiego (z którą najwybitniejsi pisarze republikańscy polemizowali już w wieku $\mathrm{XVI}$ ), ich program polityczny obejmował całe społeczeństwo, dostrzegał inne warstwy i szukał dla nich właściwego miejsca w dobrze urządzonej Rzeczypospolitej, skoro, jak twierdził Staszic, ,społeczeństwo jest jedną moralną istnością, której członkami są obywatele. Przeto prawdziwe i własne dobro każdego nie różni się od dobra towarzystwa całego" "78. Staszic zaproponował model „dobrze ułożonego towarzystwa”, w którym zagwarantowana jest „obywatelska równość, wolność i pokój”79. Jeszcze dobitniej do tej nowej zasady równości odniósł się Kołłątaj, głosząc: „Osoba człowieka, jej beśpieczeństwo jest u mnie zasadą całego Rzeczypospolitej gmachu. Rzekłem najpierw: wszelki człowiek w Polszcze zrodzony, zamieszkały lub przychodzień wolny jest, pewien swojej osoby i swojego majątku"80. Punktem wyjścia praw Rzeczypospolitej miały być prawa człowieka, uznanie, że „ziemia polska jest ziemią ludu wolnego”, zaś „,człowiek na niej stojący jest człowiekiem prawdziwie wolnym i siebie samego pewnym" "81, co przekładało się na postulat dopuszczenia do władzy prawodawczej wszystkich właścicieli, w tym mieszczan $^{82}$. Zasada równouprawnienia rozciągnięta na mieszczaństwo i dająca mu prawa polityczne (dopuszczenie stanu miejskiego do urzędów cy-

76 Wstęp, w: S. Staszic, Uwagi nad życiem Jana Zamoyskiego, wyd. S. Czarnowski, BN, Kraków 1926, s. xi-xii. „Wnioski teoretyczne wynikają u Staszica nie tylko z analizy natury człowieka samego, rozpatrywanego poza czasem i przestrzenią, ani z dociekań nad naturą państwa, jako wytworu rozumu praktycznego, - ale z badania przedmiotowego rzeczywistości społecznej samej w sobie" (tamże, s. xxxi).

77 Por. I. Stasiewicz-Jasiukowa, Człowiek i obywatel w piśmiennictwie naukowym i podręcznikach polskiego Oświecania, Warszawa 1979, s. 82 i n.

78 Staszic, Uwagi nad życiem..., s. 18.

79 Tamże, s. 49.

${ }^{80}$ H. Kołłątaj, Prawo polityczne narodu polskiego czyli uklad rządu Rzeczypospolitej, Warszawa (1790), [w: ] H. Kołłątaj, Wybór pism politycznych, oprac. B. Leśnodorski, Wrocław 1952, s. 146.

${ }^{81}$ Tamże, s. 151.

${ }^{82}$ H. Kołłątaj, Listy Anonima, t. 2, s. 97-99; tenże, Odezwa do deputacji konstytucyjnej, [w:] H. Kołłątaj, Listy Anonima i Prawo polityczne narodu polskiego, oprac. B. Leśnodorski i H. Wereszycka, Warszawa 1954, s. 178-183. 
wilnych i wojskowych oraz do prawa nabywania ziemi i udziału w prawodawstwie) miała dać szansę przekształcenia Polski z oligarchii w prawdziwą republikę: „Wolność człowieka zasadza się na wolnym używaniu swoich własności według prawa. Prawo w towarzystwie [społeczności - przyp. D.P.R.) jest wyrokiem woli wszystkich. Do ustanowienia prawa każdy obywatel albo przez siebie, albo przez swojego posła należy. Prawo, czyli woli powszechnej wyrok, nie powinno zakazywać, tylko czynności takie, co prawu wszystkich, czyli towarzystwu są szkodliwe" ${ }^{83}$. Staszic nie obawiał się sformułowania także bardziej radykalnej tezy: „Z samych panów zguba Polaków. Oni zniszczyli wszystkie uszanowanie dla prawa. Oni rządowego posłuszeństwa cierpieć nie chcąc, bez wykonania zostawili prawo. Oni zupełnie zagubili wyobrażenie sprawiedliwości w umysłach Polaków. Oni prawo zamienili w czczą formalność, która wtenczas tylko ważną była, kiedy prawo ich dumie, łakomstwu i złości służyło"84. Szedł za tym postulat nieustannego (gotowego) sejmu przy wymianie posłów co dwa lata ${ }^{85}$ oraz zasady decydowania większością głosów na Sejmie ${ }^{86}$, co oczywiście wymagało całkowitego zakazania stosowania $l i$ berum veto.

Rewizja dawnego pojęcia rzeczypospolitej zaproponowana przez Kołłątaja możliwa była dzięki rozróżnieniu dwóch rodzajów wolności - wolności politycznej, odnoszącej się do praw politycznych i wolności osobistej, będącej największą wartością społeczeństwa cywilnego, danej bowiem człowiekowi przez Naturę, z racji samego urodzenia ${ }^{87}$ (,własność osobista każdego człowieka jest najpierwszą rzeczypospolitej zasadą"88). Jeszcze bardziej istotny w tym nowym ujęciu był wątek instytucjonalny, postulat ustanowienia prawdziwego rządu zgodnego z duchem republikańskim:

Najpierwszą wadą rządu naszego jest, iż nie chcieliśmy dotąd mieć prawdziwego Rzeczypospolitej wyobrażenia. Chlubimy się na próżno nazwiskiem wolności, a w samej rzeczy konstytucja nasza wskazuje nam tylko rząd feudalny, arystokracją umiarkowany. Troskliwi o przywileje, które z rąk dobroczynnych odebraliśmy królów, nie zatrudnialiśmy się bynajmniej porządnym Rzeczypospolitej układem, upłynęło kilka wieków na ciągłych z Majestatem sporach. Nigdy zaś rzetelnie nie pomyślał naród, iż rząd republikański nie zależy od odjęcia pre-

${ }^{83}$ St. Staszic, Przestrogi dla Polski, Wrocław 2003, s. 22.

${ }^{84}$ Tamże, s. 79-80.

${ }^{85}$ Tamże, s. 212; S. Staszic, Uwagi nad życiem Jana Zamoyskiego, s. 54-55. Podobny postulat u H. Kołłątaja, Listy Anonima, t. II, s. 14-15 i n.

${ }^{86}$ S. Staszic, Uwagi nad życiem..., s. 57.

87 „Lecz rozróżnijmy tylko wolność człowieka od wolności rządowej, upewnijmy własność osobistą [...] niech będą wszyscy pod opieką wolnego rządu, niech ten rząd nie gwałci ich wolności naturalnej, a uczynimy więcej dobra dla ludzkości, niż gdybyśmy z ubogich i wyciągających ręce złożyć chcieli rządu powszechnego machinę", Listy Anonima, t. I, s. 296.

${ }^{88}$ H. Kołłątaj, Listy Anonima, t. 2, s. 13. 
rogatyw królowi, lecz na nieprzestanym działaniu osób reprezentujących naród i wolę jego wykonujących ${ }^{89}$.

Prawdziwa rzeczpospolita miała się więc opierać nie na ograniczeniu elementu monarchicznego, tak iż zażegnana została groźba absolutum dominium, której obawiali się publicyści XVII wieku oraz przywołani wyżej polemiści Kołłątaja, lecz na ustanowieniu faktycznego zwierzchnictwa wspólnoty obywatelskiej i wykonywaniu go; na tym, że to rzeczpospolita, a nie monarcha, czy zwoływany tylko od czasu do czasu sejm, faktycznie czuwa nad wszystkimi swoimi sprawami. Należało więc ustanowić trwały sejm, który postulował także Staszic, by przywrócić aktywne przedstawicielstwo Rzeczypospolitej, czyli całego narodu. Istotny jest tutaj stosunek do samej kategorii rzeczypospolitej, przekonanie, że wszyscy są bez wyjątku poddanymi Rzeczypospolitej, podlegającymi jej władzy, prawom i woli, doznający od niej ochrony. Jest tu wyraźne podkreślenie, że chodzi o wszystkich, bez względu na to, czy przysługują im prawa polityczne - czy są obywatelami, czy nie. Wreszcie postulowana naprawa Rzeczypospolitej mogła się dokonać dzięki ustanowieniu zasady sukcesji tronu ${ }^{90}$. Staszic, przeciwstawiając się krytykom, stwierdzał, że „tam, gdzie król ani w prawodawstwie osobnego stanu nie czyni, ani podatku nie stanowi, ani wojskiem hetmani, gdzie szkodzić władzy nie ma (...) - tylko wykonywania prawa jest stróżem, tam niebezpieczeństwem wolności nie grozi następstwo tronu"91.

W dyskursie tym były też wątki zupełnie nowe, zbieżne z tymi, jakie obecne były $\mathrm{w}$ republikanizmie zachodnim oraz z ustaleniami fizjokratów. Należą do nich przede wszystkim postulaty Staszica i Kołłątaja dotyczące wolnego handlu i przedsiębiorczości. Wolny handel miał nie tylko przyczyniać się do utrzymania pokoju, ale i do takiej jedności w narodzie, iżby „człowiek oczywiście wiedział, że dobro osobiste nie różni się od powszechnego dobra" ${ }^{92}$. Głoszący taki postulat autorzy polscy nie odchodzili jednak, tak jak zachodni, od klasycznego republikańskiego ideału aktywnego obywatelstwa i obywatelskiej służby, przeciwnie, poświęcali więcej uwagi edukacji obywatelskiej i obywatelskim powinnościom niż pisarze wieku XVII. Wbrew przywołanemu wyżej twierdzeniu Staszica o zależności między wolnym handlem a dobrem wspólnym, osiemnastowieczni myśliciele polityczni tacy jak John Trenchard, Henry St. John Bolingbroke czy Adam Ferguson, byli świadomi niemożności sprostania ideałowi rzeczypospolitej w sytuacji, gdy zaczynały

89 Tamże, t. I, s. 265.

${ }^{90}$ Zob. H. Kołłątaj, tamże, s. 229 oraz wcześniejsze Uwagi nad Pismem, ktore wyszło pod tytułem: Seweryna Rzewuskiego [...] o Sukcessyi tronu w Polszcze rzecz krótka.

${ }^{91}$ S. Staszic, Uwagi na życiem Jana Zamoyskiego, s. 45. Następstwo tronu miało Polskę „od dalszego podziału" zachować (tamże, s. 83).

${ }^{92}$ S. Staszic, tamże, s. 87. 
dominować prywatne interesy odsuwające jednostki od wspólnoty. Powstawała wątpliwość, widoczna zarówno u Hume'a, jak i u Monteskiusza, czy republiki, z ich naturalną skłonnością do dysput i wichrzycielstwa, będą równie skutecznie bronić praw osób, jak dobrze urządzone dziedziczne monarchie, których konstytucje zakładają mieszaną formę rządu. Nie znajdziemy u tych autorów sformułowania, którym wciąż posługiwał się Kołłątaj, tak samo jak myśliciele republikańscy XVI w.: „,wolność cnotą prowadzona"93, ani też takiego zatroskania o utrzymanie suwerenności i niepodległości, jakie towarzyszyło debacie politycznej w Rzeczypospolitej końca XVIII w. Kluczowa jednak w tym dyskursie stała się naprawa ładu instytucjonalnego, przywrócenie rządności i wprowadzenie zmian konstytucyjnych, które, obok kroczenia przez obywateli drogą prawdy i cnoty, pozwoliłyby utrzymać trwałą rzeczpospolitą, wzmocnić wspólnotę polityczną tym mianem opisaną i zabezpieczyć ją przed zagrożeniem zewnętrznym.

V. Przedstawiona tu, z konieczności dość wybiórcza, analiza służyć ma zarysowaniu kilku postulatów badawczych oraz kilku tez, dla których pełnego uzasadnienia potrzebna byłaby jednak spora monografia. Przekrojowe i porównawcze badania polskiej tradycji republikańskiej pozwalają nie tylko na lepsze osadzenie jej w kontekście europejskim ${ }^{94}$, lecz przede wszystkim na ukazanie jej specyfiki wynikającej bezpośrednio z polskiego kontekstu politycznego. Przystąpienie do badania tej tradycji wymaga jednak poczynienia szeregu rozstrzygnięć terminologicznych i metodologicznych. Ewolucja teorii republikańskiej dokonywała się stopniowo, inaczej niż na Zachodzie, a kluczowe zasady tej teorii wyrażone w samym pojęciu „rzeczpospolita” przetrwały właściwie do końca XVIII w. Tradycja ta w największym stopniu kształtowała myślenie polityczne w Rzeczypospolitej, choć z czasem rezygnowano z wysublimowanej refleksji teoretycznej, jaką formułowali autorzy szesnastowieczni, na rzecz pewnych utartych już argumentów lub postulatów praktycznych. W dyskursie republikańskim, jak pokazują choćby przywołane przeze mnie przykłady, nie zabrakło napięć i polemik, a ten sam, jak się wydawało, ideał rzeczypospolitej, wspierany był niekiedy różnymi, nawet wykluczającymi się argumentami. Wiązało się to także z zasadniczym pytaniem o to, co w największej mierze czyniło państwo rzeczą wspólną - czy jego urządzenia instytucjonalne, jak zakładała szesnastowieczna teoria Rzeczypospolitej Weneckiej, w Polsce często przywoływanej, czy „samorządzenie”, czyli uznanie wolności politycznej za fundament właściwie urządzonego, wolnego państwa, czy też towarzysząca tej wolności obywatelska cnota. Nie

93 Kołłątaj, Listy Anonima, t. I.

94 Por. R. Lis, Myśl reformatorska Sejmu Czteroletniego w świetle dylematów zachodniego republikanizmu. Zarys problematyki, „Horyzonty Polityki” 2013, t. 4, nr 7. 
ulega wątpliwości, że w XVI i w XVII wieku to pojęcie rzeczypospolitej było podstawową kategorią normatywną, która promieniowała na całą ówczesną myśl polityczną, a stąd na kulturę polityczną. W pojęciu tym skupiał się bowiem najistotniejszy element dziedziny politycznej, tj. uznanie, że wspólnota polityczna, Rzeczpospolita, jest dobrem, o które należy się troszczyć pospołu, jest ona najwyższą wartością spośród wartości politycznych, która nadaje sens innym wartościom, w tym wolności. W drugiej połowie XVIII w. przeważyło jednak podejście bardziej pragmatyczne, a kategoria rzeczypospolitej przestała odgrywać kluczową rolę, co uwidocznić miał także tekst Konstytucji 3 Maja. Uznano, że konieczne są reformy ustrojowe, bowiem bez dobrego ładu instytucjonalnego, w zepsutej rzeczypospolitej, cnota kwitnąć nie może, nie od cnoty więc należy zaczynać, lecz od mechaniki ustrojowej. Ta refleksja zbliżyła bez wątpienia nasz późny republikanizm do republikanizmu zachodniego, choć przecież nie zrezygnowano u nas z odniesienia do cnoty i obywatelskich powinności wkomponowanych już jednak w inną retorykę, opartą głównie na refleksji prawno-naturalnej, formułowaną już nie pod wpływem Arystotelesa i Cycerona, lecz przede wszystkim Rousseau.

\section{CONTINUATION AND CHANGE IN POLISH REPUBLICANISM OF THE SEVENTEENTH AND EIGHTEENTH CENTURIES}

\section{Summary}

The republican tradition of the First Polish Republic (Rzeczpospolita) evolved from the period between the sixteenth and the eighteenth century, producing an extremely reach conceptual understanding of politics. The aim of this article is to explore and discuss both the continuity and change that took place in the Polish republican discourse in the seventeenth and eighteenth centuries. I argue that these changes had a different character from those that were typical of western republicanism (especially in England and America) which was much more open to new political concepts. Moreover, its transformation, unlike in the Polish republican tradition, led to a departure from the classical idea of res publica allowing republican ideas to merge with new concepts such as constitutionalism, individual rights, protection of private property and entrepreneurship. It was only towards the end of the eighteenth century that Polish authors adopted a similar approach, trying to implement a somewhat modified republican framework in response to the difficult political situation of Rzeczpospolita. 


\title{
LA CONTINUITÉ ET LES CHANGEMENTS DANS \\ LE RÉPUBLICANISME POLONAIS DU XVII ${ }^{\mathrm{E}}$ ET XVIII ${ }^{\mathrm{E}}$ SIÈCLE
}

\begin{abstract}
Rés umé
L'article est une tentative de faire les premières constatations concernant les changements survenus dans le discours républicain polonais au XVII et $\mathrm{XVIII}^{\mathrm{e}}$ siècle d'une part, et la continuité qui caratérise en grande partie ce discours, de l'autre. Il s'agit en l'occurrence de démontrer avant tout que, selon l'idée républicaine polonaise, les changements avaient d'autres caractéristiques que ceux rencontrés dans le républicanisme occidental qui commence à s'éloigner du modèle classique appelé la res publica et devient à l'époque de plus en plus ouvert aux nouveaux concepts politiques (notamment en Angleterre et en Amérique), tels que le constitutionnalisme, les droits de l'individu, la protection de la propriété privée, l'esprit d'entreprise. Le républicanisme polonais ne commence à s'ouvrir à la startégie similaire qu'à la fin du $\mathrm{XVIII}^{\mathrm{e}}$ siècle. Ce phénomène est une réponse à la situation politique de plus en plus difficile dans laquelle se trouve la République. Une vive reprise du discours politique dont l'essor est constaté pendant les séances de la Diète de quatre ans et les débats sur la Constitution du 3 Mai aura donc pour effet les tentatives d'intégrer dans le discours républicain les nouvelles idées telles que les droits naturels de l'homme et la liberté personnelle, sans oublier pourtant complètement les décisions antérieures.
\end{abstract}

